\title{
The effect and mechanism of action of volatile fatty acids on the catabolism of progesterone
}

\author{
Darron Louis Smith \\ West Virginia University
}

Follow this and additional works at: https://researchrepository.wvu.edu/etd

\section{Recommended Citation}

Smith, Darron Louis, "The effect and mechanism of action of volatile fatty acids on the catabolism of progesterone" (2005). Graduate Theses, Dissertations, and Problem Reports. 2322.

https://researchrepository.wvu.edu/etd/2322

This Dissertation is protected by copyright and/or related rights. It has been brought to you by the The Research Repository @ WVU with permission from the rights-holder(s). You are free to use this Dissertation in any way that is permitted by the copyright and related rights legislation that applies to your use. For other uses you must obtain permission from the rights-holder(s) directly, unless additional rights are indicated by a Creative Commons license in the record and/ or on the work itself. This Dissertation has been accepted for inclusion in WVU Graduate Theses, Dissertations, and Problem Reports collection by an authorized administrator of The Research Repository @ WVU.

For more information, please contact researchrepository@mail.wvu.edu. 
The Effect and Mechanism of Action of Volatile Fatty Acids on the Catabolism of Progesterone

Darron Louis Smith

Dissertation submitted to the

Davis College of Agriculture, Forestry, and Consumer Sciences at West Virginia University

in partial fulfillment of the requirements

for the degree of

Doctor of Philosophy

in

Reproductive Physiology

Matthew E. Wilson, Ph.D., Chair

E. Keith Inskeep, Ph.D.

Paul E. Lewis, Ph.D.

Kenneth P. Blemings, Ph.D.

Harold H. Harpster, Ph.D.

Division of Animal and Veterinary Sciences

Morgantown, WV

2005

Keywords: Acetate, Propionate, Insulin, Glucagon, Progesterone, Sheep 


\title{
ABSTRACT \\ The Effect and Mechanism of Action of Volatile Fatty Acids on the Catabolism of Progesterone
}

\author{
Darron Louis Smith
}

\begin{abstract}
Factors that affect the clearance of progesterone by the hepatocyte were examined. In study one, the objective was to determine if increased hepatic portal acetate or propionate could alter hepatic metabolism of progesterone. Serum concentrations of progesterone after an oral gavage of either acetate or propionate began to diverge as early
\end{abstract} as $0.5 \mathrm{~h}$ and were different $(\mathrm{P}<0.05)$ at 3 -h $(1.09 \pm 0.09 \mathrm{ng} / \mathrm{ml}$ vs. $2.04 \pm 0.48 \mathrm{ng} / \mathrm{ml})$ and 4 -h $(1.20 \pm 0.09 \mathrm{ng} / \mathrm{ml}$ vs. $1.95 \pm 0.41 \mathrm{ng} / \mathrm{ml})$ for ewe lambs gavaged with acetate or propionate, respectively. Increasing portal vein propionate reduced progesterone clearance. In study two, the objective was to determine the effect of a single oral gavage of either acetate or propionate on peripheral concentrations of insulin and glucagon in the ewe. Serum concentrations of insulin, after an oral gavage of either acetate or propionate, were different $(\mathrm{P}<0.05)$ at $0.5 \mathrm{~h}(0.14 \pm 0.04 \mathrm{nM}$ vs. $0.63 \pm 0.08 \mathrm{nM})$ and 1 $\mathrm{h}(0.12 \pm 0.04 \mathrm{nM}$ vs. $0.23 \pm 0.04 \mathrm{nM})$ for ewe lambs orally-gavaged with acetate and propionate, respectively. Further, serum concentrations of glucagon, after an oral gavage of either acetate or propionate, were different $(\mathrm{P}<0.05)$ at $0.5 \mathrm{~h}(0.019 \pm 0.002 \mathrm{nM}$ vs. $0.048 \pm 0.007 \mathrm{nM}), 1 \mathrm{~h}(0.021 \pm 0.004 \mathrm{nM}$ vs. $0.041 \pm 0.006 \mathrm{nM})$ and $2 \mathrm{~h}(0.016 \pm 0.003$ $\mathrm{nM}$ vs. $0.033 \pm 0.006 \mathrm{nM}$ ) for ewe lambs orally-gavaged with acetate and propionate, respectively. The last study determined progesterone clearance in response to challenge with different concentrations of insulin, glucagon or a combination of insulin and glucagon in a hepatic cell line. In response to a challenge with insulin, there was a dose dependant decrease in the disappearance of progesterone. There was a reduction $(\mathrm{P}<$ 0.05 ) in the rate of decay with the addition of $0.1 \mathrm{nM}$ insulin, when compared to control. Further, there was a greater reduction $(\mathrm{P}<0.05)$ in the rate of decay in response to 1.0 and $10 \mathrm{nM}$ insulin than control and $0.1 \mathrm{nM}$ insulin. There was no observable change in the disappearance of progesterone with either physiological $(0.01 \mathrm{nM})$ or pharmacological (0.1 and $1.0 \mathrm{nM})$ treatment with glucagon. Pharmocological concentrations of glucagon $(1.0 \mathrm{nM})$ negated the effects of either 0.1 or $1.0 \mathrm{nM}$ insulin on the clearance of progesterone. However, with physiological concentrations of glucagon $(0.01 \mathrm{nM})$ and $1.0 \mathrm{nM}$ insulin, glucagon was not able to negate the reduction in progesterone disappearance caused by insulin. These data show that when animals have high concentrations of insulin, hepatocytes exhibit a reduced catabolism of progesterone. 


\section{TABLE OF CONTENTS}

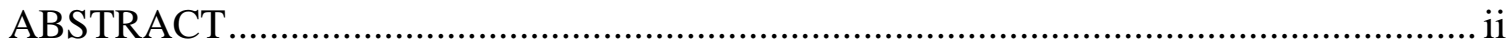

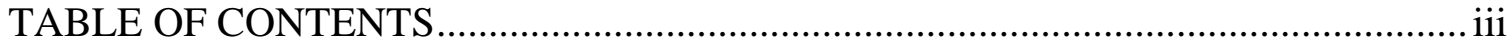

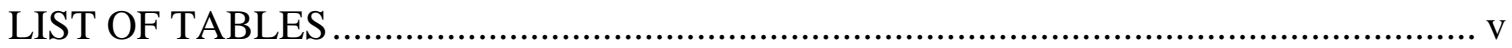

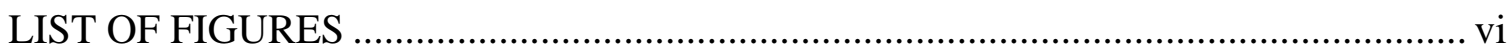

ACKNOWLEDGEMENTS ...................................................................................... vii

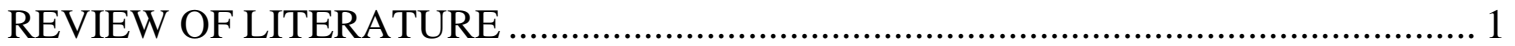

Progesterone and Maintenance of Pregnancy ………............................................... 1

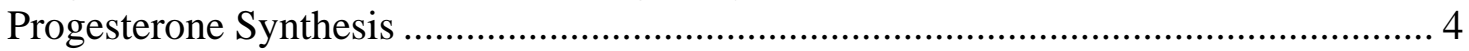

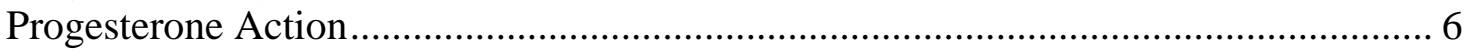

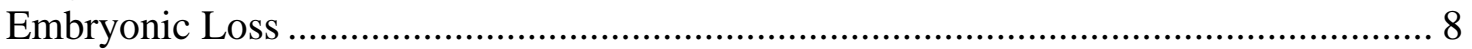

Progesterone Catabolism ........................................................................................ 9

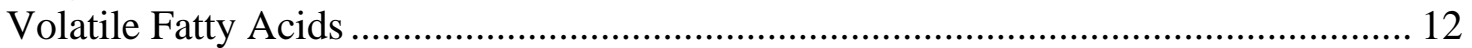

Volatile Fatty Acids and Glucose Production.................................................................. 13

Liver Blood Flow and Volatile Fatty Acids................................................................ 14

Insulin, Glucagon, and Volatile Fatty Acids Interaction ............................................. 15

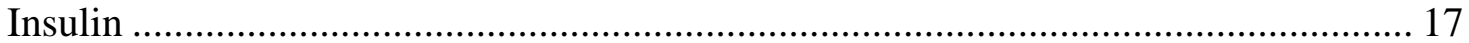



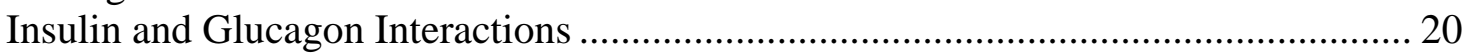

STATEMENT OF THE PROBLEM ...................................................................... 22

EFFECT OF ACETATE OR PROPIONATE ON THE CLEARANCE OF PROGESTERONE IN THE SHEEP ………………............................................ 24

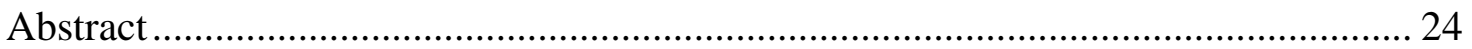

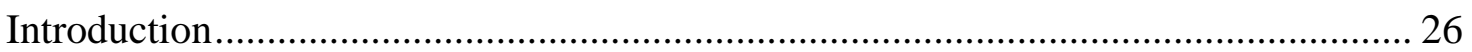

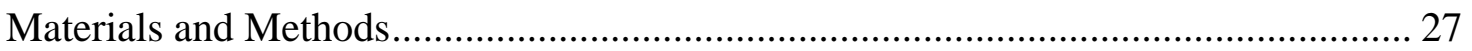

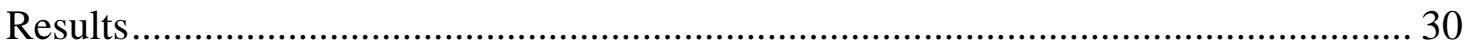

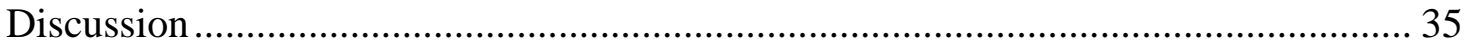

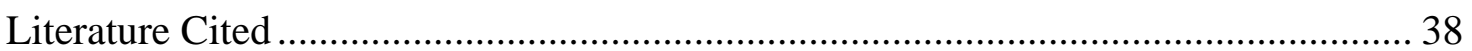

EFFECT OF ACETATE OR PROPIONATE ON CIRCULATING

CONCENTRATIONS OF INSULIN OR GLUCAGON IN THE EWE........................... 40

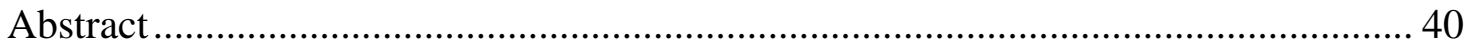

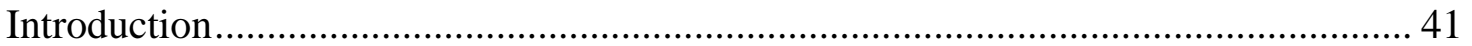

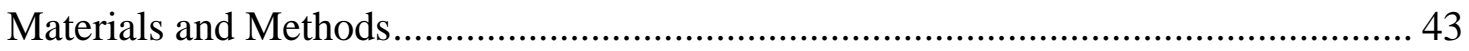

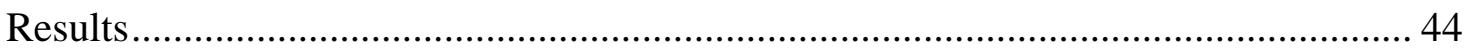

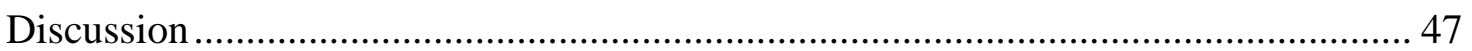

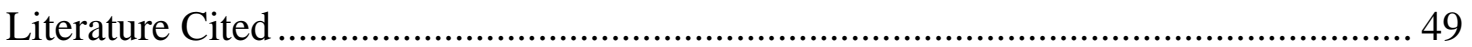

ALTERATIONS IN THE RATE OF PROGESTERONE CLEARANCE INDUCED BY INSULIN, GLUCAGON, OR INSULIN TO GLUCAGON RATIO, IN A MOUSE HEPATIC CELL LINE........................................................................................ 51

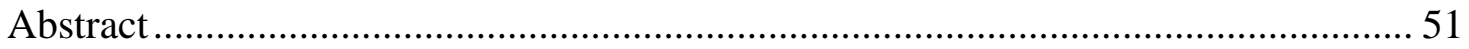

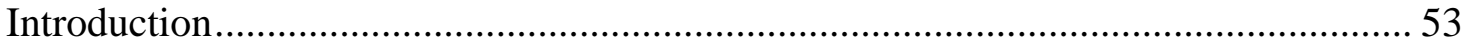

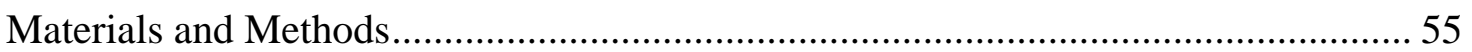

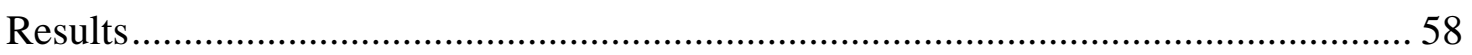

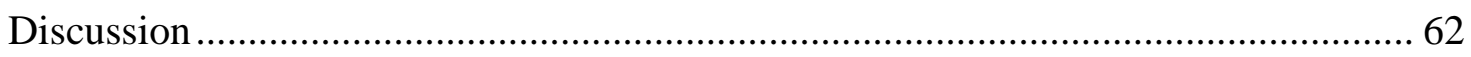

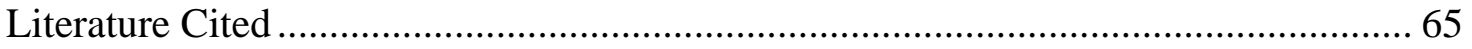

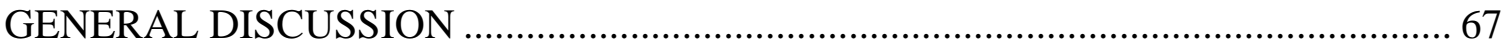


LITERATURE CITED

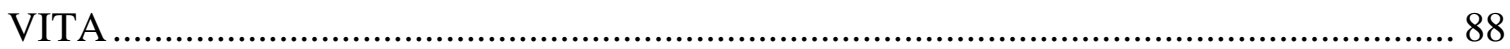




\section{LIST OF TABLES}

Table 1: Concentrations of acetate and propionate (mM) in jugular vein plasma following feed alone or feed plus an oral gavage of $0.146 \mathrm{Mcal} / \mathrm{d}$ of acetate or propionate. ... 33 


\section{LIST OF FIGURES}

Figure 1: The hepatic portal vein concentration of acetate following feed alone or feed plus an oral gavage (0.146 Mcal) of acetate or propionate.

Figure 2: The hepatic portal vein concentration of propionate following feed alone or feed plus an oral gavage (0.146 Mcal) of acetate or propionate.

Figure 3: Concentration of serum progesterone (mean \pm SEM) following a single oral gavage $(0.146 \mathrm{Mcal})$ of acetate or propionate. Asterisks denote differences $(\mathrm{P}<0.05)$ between the acetate and propionate treatments

Figure 4: The jugular vein concentration of insulin following an oral gavage (0.146 Mcal) of acetate or propionate. Means \pm SEM with different letters differ $(\mathrm{P}<$ $0.05)$ 45

Figure 5: The jugular vein concentration of glucagon following an oral gavage (0.146 Mcal) of acetate or propionate. Means \pm SEM with different letters differ ( $\mathrm{P}<$ $0.05)$

Figure 6: Number of hepatocytes per well during 6 h of culture in media containing 5 $\mathrm{ng} / \mathrm{ml}$ of progesterone. 56

Figure 7: The fractional rate of decay of progesterone, by cells, challenged with $0,0.1,1$ and $10 \mathrm{nM}$ insulin. Means \pm SEM with different letters differ $(\mathrm{P}<0.05)$ 59

Figure 8: The fractional rate of decay of progesterone, by cells, challenged with $0,0.01$, 0.1 and $1.0 \mathrm{nM}$ glucagon. Means \pm SEM with different letters differ $(\mathrm{P}<0.05) \ldots 60$ 
Figure 9: The fractional rate of decay of progesterone, by cells, challenged with different ratios of insulin and glucagon ( 0 and $0,1.0$ and 1.0, 1.0 and 0.1 or 0.1 and 1.0, nM insulin and glucagon, respectively). Means \pm SEM with different letters differ $(\mathrm{P}<$

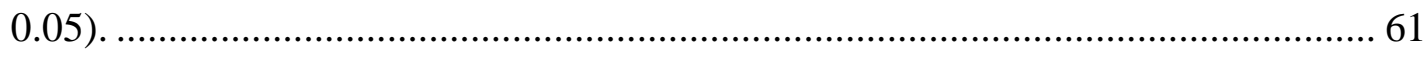




\section{ACKNOWLEDGEMENTS}

It is hard to acknowledge all those who have made significant contributions to my education. I will do my best to recognize everyone, but please keep in mind there are numerous others who should be acknowledged. To everyone, mentioned or those that should have been, thank you for everything!

Dr. Wilson has been my friend, mentor, educator and sometimes my advisee. His positive outlook in life, through all challenges is an inspiration. Maybe he quizzes a little too much, especially during playtime, but everyone who associates with him is a much more educated and knowledgeable person. Finally, those who are fortunate enough to be his friend are lucky indeed. I would not be where I am today without his help.

Dr. Inskeep is truly one of the most knowledgeable professors on reproductive physiology. His recall and grasp of literature is amazing. He is one of the most valuable assets to the Reproductive Physiology program at West Virginia University. I enjoyed working with him and learned a great deal from him.

Dr. Lewis is passionate about education as well as the Division of Animal and Veterinary Science. As Division Director (sometimes a thankless job), Dr. Lewis is efficient and professional. His ability to work with a diversified population is unique and amazing to observe. Dr. Lewis taught me to be more diplomatic and considerate of others' opinions, but in the end you have to do what's right.

Dr. Blemings worked hard to teach me biochemistry, and invited me to his journal club and seminars. He advised me on my research and made it possible for me to do the 
cell culture experiment. I'd love to say I was a biochemistry expert now but I don't think I will ever be. However, no one could have taught me more in such a short time.

Dr. Harpster has been instrumental in my college education from my first days as an undergraduate student to the completion of my doctoral degree. One of my fondest memories in life is my time spent on Tadpole Road. Dr. Harpster is extremely tenacious as he has been helping me with my education for twenty years, but more importantly he is my friend and I will always be grateful for that.

Numerous other Drs. Have made significant impacts on my education, two of which stand out. Dr. Richard Russell who was on my committee from the start and the first professor to try and teach me biochemistry. He participated in the design of my first experiment. Unfortunately, he passed at an early age, and I missed having him continue to work with me. Dr. Lowell Wilson, a professor emeritus from The Pennsylvania State University has been and still is my mentor and friend. No one has done more to advance my career than him both in agriculture and research. I could never say enough about Dr. Wilson except, to thank him.

To all the graduate students and all the undergraduates I taught, they all helped educate me in some way. Jill Koch, Beth Stienfelt, and Beth Costine all helped with my experiments and data collection. I am most grateful to them for their help.

To those that know me, my family is the most important thing to me. Kimberly Jo Smith, my wife, advises me, works with me, supports me, motivates me, and most importantly loves me. I am truly fortunate to have her for my partner she completes me. Every moment of every day I am a better person because of her. 
My Father and Mother, it says to honor thy mother and father, I’m sure I didn't always do that and I probably should have. However, they are the two most favorite people in my life and more importantly they are now my friends. No one had better parents than I do. They have not missed one important event in my life from sports events to graduations and when the life has been too much and wore me out, they carried me. I dedicate this dissertation to my parents.

My boys, Cody, Isaac, Andrew, and Nicky, they bring stress, trouble and all manner of disaster, yet each provides so much. Cody has been with me the longest and is supportive in all my endeavors he is now my friend (almost). Isaac the determined, no one will ever run over him. Andrew is sensitive and caring and Nicky is the little wild man. For all the disasters and other mishaps, I love having them in my life they are all such good boys.

Thank you to everyone, education is a community project and I've been fortunate in my life to have a great community. 


\section{REVIEW OF LITERATURE}

\section{Progesterone and Maintenance of Pregnancy}

Secretion of progesterone by the corpus luteum is necessary for the maintenance of pregnancy (Prenant, 1898; Hess, 1920; Schmaltz, 1921; Hammond, 1927; McDonald et al., 1952; McDonald et al., 1953; Estergreen et al., 1967). In the cow, luteal progesterone is required throughout gestation (Raeside and Turner, 1950). However, in the sheep, the placenta secretes enough progesterone to maintain pregnancy from day 50 of gestation (Casida and Warwick, 1945).

It can be surmised that variations in peripheral concentrations of progesterone are a result of variations in the production and/or catabolism of progesterone. Some reports have indicated beneficial effects of exogenous progestogen supplementation (Wiltbank et al., 1956; Johnson et al., 1958; Kunkel et al., 1977; Robinson et al., 1989) while others have not been able to demonstrate any benefit of exogenous progestogen (Sreenan et al., 1979; Sreenan and Diskin, 1983; Stevenson and Mee, 1991) on pregnancy rates in cattle. However, it has been shown that cows treated with exogenous progesterone on days 1-4 of pregnancy exhibit altered histotrophic composition and embryos were more advanced than control animals by day 5 of pregnancy (Garret et al., 1988).

In the cow, the minimum production of progesterone by the corpus luteum necessary to maintain pregnancy has been estimated by replacement therapy following the removal of the corpus luteum. Raeside and Turner (1950) surgically removed the corpus luteum followed by daily administration of $50 \mathrm{mg}$ of progesterone, which resulted in $50 \%$ pregnancy retention. McDonald et al. (1952) were able to maintain 2 of 6 pregnancies in lutectomized Holstein cows by daily intramuscular administration of 75 
mg of progesterone between days 57 and 63. Three of six Holstein heifers maintained pregnancy following surgical removal of the corpus luteum between days 60 and 96 followed by daily treatment with 125 mg of progesterone intramuscularly (Johnson and Erb, 1962). Tanabe (1966; 1970) investigated the minimum amount of one intramuscular injection of progesterone necessary to maintain pregnancy in dairy cows at 11 different stages of gestation for 10 days. The minimum concentration of progesterone in a slowrelease vehicle necessary at day 30 to maintain pregnancy in cows for 10 days was 0.75 mg per kilogram of body weight, injected intramuscularly. Bridges et al. (2000) achieved successful maintenance of pregnancy in beef cows by twice daily subcutaneous injections of $150 \mathrm{mg}$ of progesterone.

In cattle, contrary to reported changes in the concentration of progesterone in response to underfeeding, numerous researchers have shown that alterations in nutrition did not have consistent effects on the concentrations of progesterone in nulliparous heifers (Folman et al., 1973; Apgar et al., 1975; Spitzer et al., 1978; Easdon and Chesworth, 1980). There was no significant difference between the concentration of plasma progesterone in three heifers fed at maintenance when compared to being fed $50 \%$ of maintenance (Chesworth and Easdon, 1983). Many of the demonstrated effects of nutrition on concentrations of progesterone in the cow result from severe undernutrition, which prevented the growth of follicles and therefore the formation of the corpus luteum, completely precluding any opportunity for conception (Holness et al., 1979; Chesworth and Easdon, 1983).

Concentrations of progesterone were approximately 25\% lower in heifers fed a high energy diet as compared to those fed a low energy diet, which may have been a 
result of increased clearance (Nolan et al., 1998). In lactating dairy cows, the clearance of progesterone may be increased due to high dietary protein (Westwood et al., 1998). During the breeding period, any increase in the clearance of progesterone due to high dietary intake may be combined with the effects of a negative energy balance to reduce concentrations of progesterone and fertility (Butler, 2000). During the fifth week of pregnancy in lactating dairy cows, embryonic survival was less in cows with progesterone concentrations in the lowest quartile (Starbuck, 2001).

In sheep bled every 10 days throughout gestation, plasma progesterone increased from 2 to $3 \mathrm{ng} / \mathrm{mL}$ in early pregnancy to approximately 10 to $20 \mathrm{ng} / \mathrm{mL}$ on d 130 to 140 of gestation and fell to $1 \mathrm{ng} / \mathrm{mL}$ at parturition (Bassett et al., 1969). Further, utilizing ewes fed below and in excess of maintenance, Parr et al. (1987) showed that at least 2 $\mathrm{ng} / \mathrm{mL}$ of progesterone were necessary for a normal conception rate. In the ewes fed in excess of maintenance, resulting in reduced concentrations of progesterone, pregnancy rate was restored with exogenous progesterone (Parr et al., 1987).

The sheep embryo is particularly sensitive to reductions in peripheral concentrations of progesterone over a 48-h period on d 11 and 12 of pregnancy (Parr, 1992). However, progesterone concentrations greater than 4 to $5 \mathrm{ng} / \mathrm{mL}$ in early pregnancy caused reductions in pregnancy rate (Parr et al., 1987). Concentrations of progesterone peaked on days 11 to 15 which were consistent with the idea that progesterone is responsible for the rapid preimplantation growth phase of the embryo (Bindon, 1971). Peak concentrations of progesterone on days 11 and 12 of the estrous cycle were reduced when ewes were fed at two times maintenance energy requirement (Lamond et al., 1972). It has also been shown that within the first three weeks of 
pregnancy concentrations of progesterone were elevated when ewes were fed a submaintenance diet (Cummings et al., 1971; Parr et al., 1982). When underfed, ovariectomized pregnant ewes were given exogenous progesterone, peripheral concentrations of progesterone were elevated compared to ones that were not underfed (Parr et al., 1982). These differences in progesterone concentartions indicates that the effects of nutrition may impact the metabolic clearance rate, rather than synthesis, of progesterone by the corpus luteum (Parr et al., 1982). However, Boone et al. (1975) showed that well fed ewes had a slightly higher concentration of progesterone than poorly fed ewes. This increase was significant on day 8 of the estrous cycle, but not in pregnant ewes.In the cow, the effects of nutrition on concentrations of progesterone were equivocal. Some authors have shown that the effects of under nutrition on concentrations of progesterone were temporary while others demonstrated permanent effects (Staigmiller et al., 1979; Beal et al., 1978). Hill et al. (1970) reported that the reduction in the concentration of progesterone lasted for only the first cycle. Other experiments demonstrated that undernutrition caused concentrations of progesterone to rise for one cycle followed by a decrease the next cycle (Donaldson et al., 1970; Gombe and Hansel, 1973). Dunn et al. (1974) reported concentrations of progesterone were increased when beef cattle were fed a restricted diet. Finally, increased feed intake increased liver blood flow and progesterone metabolism in both lactating and non-lactating dairy cattle (Sangsritavong et al., 2002).

\section{Progesterone Synthesis}

Cholesterol is the substrate for steroidogenesis. The liver synthesizes the majority of cholesterol (as reviewed by Krisans, 1996), and it is transported to steroidogenic 
tissues such as the adrenal cortex, follicle, corpus luteum, placenta, or testes, by the blood. Cholesterol is transported through the blood as a component of lipoprotein particles, and the most common blood born cholesterol sources for steroid production are low-density and high-density lipoprotein particles, which are composed of apolipoproteins and lipids (Ohashi et al., 1982; Pate and Condon, 1982; Hwang and Menon, 1983).

Low-density lipoprotein particles are transported into the luteal cell by receptormediated endocytosis (Brown and Goldstein, 1986). Once in the cell, the endosomes combine with lysosomes and the low-density lipoprotein particle is disassociated from its receptor, thus freeing approximately 2500 molecules of cholesterol (Grummer and Carroll, 1988). High-density lipoprotein particles binds to a plasma membrane-bound high-density lipoprotein binding protein, and the high-density lipoprotein particle is transported into the cell by a mechanism that is not receptor mediated (Lestavel and Fruchart, 1994; Assanasen et al., 2005).

In the cytosol, cholesterol can be used for steroidogenesis or other cellular functions. Cholesterol also may be esterified with fatty acids to form cholesterol esters by the enzyme cholesterol ester synthetase (as reviewed by Johnson et al., 1997). The cholesterol esters can be stored as lipid droplets. These droplets have been used as a morphological determinant of steroidogenic cellular phenotype. When the steroidogenic cell needs cholesterol, the enzyme cholesterol esterase hydrolyzes the cholesterol esters stored in the lipid droplet to provide free cholesterol for the cell (Caffrey et al., 1979).

Steroidogenesis is dependent on cholesterol being transported through the cytoplasm to the outer and then the inner mitochondrial membrane (Stone and Hechter, 
1954). An intact cytoskeleton is required for cholesterol transport. It has been shown that inhibitors of both microtubule and microfilament assembly prevent the movement of cholesterol to the outer mitochondrial membrane (Crivello and Jefcoate, 1978). The ratelimiting step in the steroidogenic pathway is the transport of cholesterol from the outer to the inner mitochondrial membrane. Steroidogenic acute regulatory protein transports cholesterol from the outer to the inner mitochondrial membrane when it is inserted into the membrane (Waterman, 1995). In addition to steroidogenic acute regulatory protein, a peripheral-type benzodiazepine receptor is present in the membrane of the mitochondria (Tsai et al., 1996). When the gene for this receptor has been deleted, steroid production is dramatically reduced, and synthesis is restored upon reinsertion of the receptor (Papadopoulos et al., 1997). Both steroidogenic acute regulatory protein and the benzodiazepine receptor appear to be necessary for normal transport of cholesterol from the outer to the inner mitochondrial membrane (Niswender, 2000).

In the inner mitochondrial membrane the enzyme P450 side chain cleavage, adrenodoxin and adrenodoxin reductase cleave the side chain from cholesterol to form pregnenolone (Stone and Hechter, 1954). Pregnenolone is then transported to the smooth endoplasmic reticulum, which is closely associated with the mitochondria. In the smooth endoplasmic reticulum, pregnenolone is converted to progesterone by the enzyme 3 betahydroxysteroid dehydrogenase ${ }^{\Delta 4,5}$ isomerase (Hanukoglu, 1992). Progesterone does not appear to be stored and moves freely out of the cell.

\section{Progesterone Action}

The ability of progesterone to maintain pregnancy has been well documented. The hypothalamic-pituitary axis and the reproductive tract are the main targets for 
progesterone (Niswender et al., 2000). Most of the effect of progesterone is mediated by progesterone binding to its nuclear receptors, which in turn bind to specific progesterone response elements on the DNA that regulate transcription (Moutsatsou and Sekeris, 1997).

In livestock species, production of progesterone receptors in the reproductive tract requires previous exposure to estradiol (Kaneko et al., 1993; Kraus and Katzenellenbogen, 1993; Ing and Tornesi, 1997), conversely, progesterone downregulates estrogen receptors (Brenner et al., 1974; Evans and Leavitt, 1980; West et al., 1987; Iwai et al., 1995). Further, progesterone blocks secretion of estradiol-stimulated proteins (Verhage and Fazleabas, 1988). Finally, the half-life for messenger RNA that encode for hormone receptors are regulated by their own hormones, either by positive or negative feedback loops that limit or augment hormonal response (Ing, 2005).

Progesterone caused quiescence of the myometrium by preventing the expression of gap junctions between the myometrial cells (Parkington, 1983). Progesterone decreased the expression of genes that encode voltage-gated calcium channels (Tezuka et al., 1995), which decreased the uptake of extracellular calcium that is required for contraction (Bartol et al., 1985). Progesterone also blocked the ability of estrogens to induce alpha-adrenergic receptors, which can cause myometrial contractions (Bottari et al., 1983).

In the hypothalamus, progesterone blocked the surge secretion of gonadotropin releasing hormone (Attardi and Happe, 1986; Kasa-Vubu et al., 1992). Progesterone also reduced the number of pituitary gonadotropin releasing hormone receptors by downregulating the mRNA for the receptor. This reduction in gonadotropin releasing 
hormone caused a reduction in the release of luteinizing hormone partly by a reduction in gonadotropin releasing hormone receptors in the pituitary (Janovick and Conn, 1996). High concentrations of progesterone decreased expression of the genes that encode for the beta-subunit of both luteinizing hormone (Brann et al., 1993) and follicle-stimulating hormone (Brann et al., 1993; Digregorio and Nett, 1995). Furthermore, the gene that encode the alpha subunit, common to the gonadotropins, was downregulated by progesterone (Brann et al., 1993; Digregorio and Nett, 1995; Attardi et al., 1997).

\section{Embryonic Loss}

Embryonic mortality can be caused by either environmental or genetic factors (Ayalon, 1978; King, 1991; Kastelic, 1994). Environmental factors include both internal and external factors. Internal factors include the uterine environment, the maternal hormonal milieu and hormones secreted by the embryo. External factors would include things such as nutrition, disease, or ambient temperature. If the embryo was surgically removed or died before day 15 in the cow (Northey and French, 1980), or day 12 in the ewe, the inter-estrous interval remained the same as the estrous cycle (Moor and Rowson, 1966). If the embryo died after this time, the estrous cycle was extended because maternal recognition of pregnancy had occurred.

In cattle, Maurer and Chenault (1983) reported that $67 \%$ of embryonic mortality occurred by day 8. Similarly, Diskin and Sreenan (1980) showed the majority of embryonic loss occurred by day 16; while Dunne et al. (2000) reported that the loss occurred by day 14. Embryonic loss after maternal recognition of pregnancy has been estimated between $7 \%$ to $12 \%$ with the majority occurring between days 24 to 75 as determined by concentrations of progesterone in milk (Kummerfield, et al., 1978; 
Bulman and Lamming, 1979). For lactating dairy cows on a timed insemination protocol, estimates of embryonic loss between day 28 and 42 ranged from $13.3 \%$ (Cartmill et al., 2000) to 45.9 \% (El-Zarkouny, et al., 2000). Inskeep (2002) reviewed data showing that regardless of synchronization treatment, or the stage of the cycle, embryonic loss ranged from $15 \%$ to $30 \%$ in timed inseminated lactating dairy cattle.

In sheep, Bolet (1986) calculated embryonic and fetal loss to be $30 \%$. Others have reported most of the loss occured before day 18 of gestation (Moor and Rowson, 1960; Quinlivan et al., 1966). Hulet et al. (1956) estimated embryonic/fetal loss to be 9.4 $\%$ after day 18. Similarly, Moor and Rowson (1960) reported that the majority of loss after day 18 occurred post attachment, which occurred at approximately day 20. Fetal loss after day 30 to parturition was estimated to be low (Robinson, 1951; Quinlivan et al., 1966). Researchers have shown in sheep that individual embryos can be lost without the total loss of pregnancy (Rhind et al., 1980; Schrick and Inskeep, 1993). Further, Quinlivan et al. (1966) reported that $54 \%$ of ewes had twin ovulations, but only had one embryo on day 18 , however, only $3.9 \%$ of ewes lost all embryos. Similarly, Dixon (2004) showed that late embryonic and fetal losses from ovulation to term were more often partial losses than complete loss. In fact, Dixon (2004) calculated the total loss from ovulation to term to be $50.4 \%$, with approximately three percentage points of loss occurring during every 20-day period throughout gestation (Dixon, 2004).

\section{Progesterone Catabolism}

Progesterone is a short half-life steroid that is degraded rapidly by the liver (Miller et al., 1963; Estergreen et al., 1977; Clemens and Estergreen, 1982; Rico, 1983), with the breakdown products being excreted in the feces and urine (Taylor, 1971; Parr, 
1992). Experiments employing radioinfusion $\left({ }^{14} \mathrm{C}\right.$-progesterone $)$ in domestic ruminants have demonstrated that the predominant route of excretion of radioactive metabolites was through the bile and feces (Williams, 1962; Stupnicki et al., 1969; Estergreen et al., 1977, Palme et al., 1996). Therefore, the analysis of fecal progesterone metabolites is a possible method for classifying ovarian function and/or for pregnancy detection, as it has been used in cattle (Desaulniers et al., 1989; Bamberg and Schwarzenberger, 1990; Klingler, 1991; Larter et al., 1994). Fecal progesterone metabolites were characterized in immunoassays utilizing antibodies generated against 4-pregnene-3, 20-dione (progesterone; Desaulniers et al., 1989; Klingler, 1991; Kirkpatrick et al., 1993; Larter et

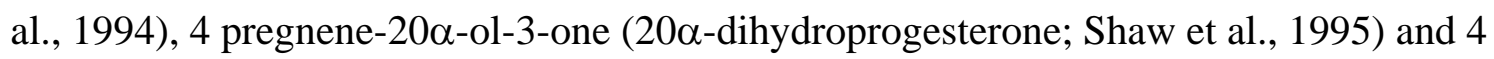

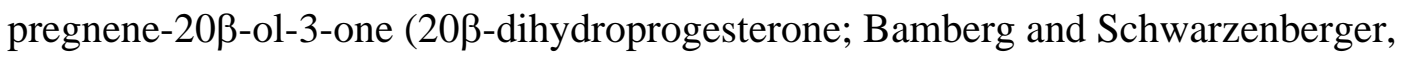
1990).

Research on the catabolism of radioactively-labeled progesterone (Shideler et al., 1993; Brown et al., 1994), and studies using high performance liquid chromatographic separation of fecal extracts and subsequent immunoassay analysis (Shideler et al., 1993; Brown et al., 1994) showed that progesterone was metabolized before excretion into the feces. In most cases, there are a number of progesterone metabolites excreted, which were described as pregnanediones and mono- and di-hydroxylated pregnanes (Schwarzenberger et al., 1996). There was little if any, non-catabolized progesterone in the feces (Schwarzenberger et al., 1996). Therefore, utilizing very specific progesterone antibodies may have underestimated the total amount of fecal progesterone metabolites (Schwarzenberger et al., 1996). 
Researchers have utilized antibodies raised against 6-hydroxysteroid progesterone (Klingler, 1991) and 20ß-dihydroprogesterone (Bamberg and Schwarzenberger, 1990) to determine fecal progesterone metabolites during the estrous cycle of cows. The measurement of fecal metabolites was sensitive enough to identify the follicular and the luteal phases, but differences in progesterone metabolites in the transition between follicular and luteal phase were too small to make this suitable for classification of stage of cycle.

Cytochrome P450 enzymes, particularly CYP3A4 and CYP2C19, contribute substantially to the hepatic catabolism of progesterone (Miller et al., 1963; Estergreen et al., 1977; Clemens and Estergreen, 1982; Rico, 1983; Guay, 1998; Bidstrup et al., 2003). Numerous researchers have shown that the CYP2C family of enzymes, especially CYP2C19, overlap in metabolic function with the more prominent CYP3A4 in progesterone metabolism (Kerr et al., 1994; Sonnichsen et al., 1995; Yamazaki et al., 1997; Muck, 2000; Tang et al., 2000). Bidstrup et al. (2003) confirmed that the in vitro metabolism of progesterone was a NADPH-dependent process and that the activity of

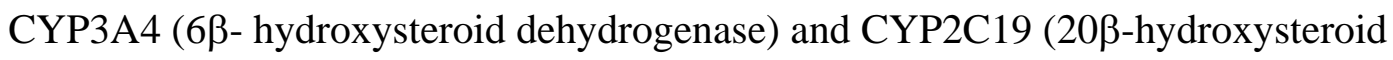
dehydrogenase) resulted in the formation of the major metabolites including $6 \beta$ hydroxyprogesterone and 20 $\alpha$-hydroxyprogesterone, respectively.

Both CYP3A4 and CYP2C19 catabolize many different substrates and competition among these substrates for binding sites, or limitations in enzymatic cofactors, may alter the ability of cytochrome P450 enzyme to metabolize a given substance (Bidstrup et al., 2003). 


\section{Volatile Fatty Acids}

As reviewed by Bergman (1990), volatile fatty acids contain 1 to 7 carbon atoms and are either straight or branch chained compounds. The volatile fatty acids include formic, acetic, propionic, butyric, isobutyric, valeric, isovaleric, 2-methylbutyric, hexanoic, and heptanoic acid. The predominant forms of volatile fatty acids are acetic, propionic and butyric and are produced from the fermentation of plant materials such as celluloses, fiber, starches, and sugars. Mammals do not produce enzymes that are able to break down long chain structural carbohydrates and so such breakdown requires microbial fermentation. Therefore, volatile fatty acids are produced in the greatest quantity in herbivores. Herbivores can be further categorized as foregut or hindgut fermentors. The foregut fermentors have a fermentation chamber cranial to the gastric portion of the stomach, whereas hindgut fermentors have fermentation chambers caudal to the gastric stomach. Regardless of the site of fermentation, the major substrates are complex carbohydrates originating from plant cells. The common molar ratios of acetate, propionate and butyrate produced from microbial fermentation of plant carbohydrates vary from 75:15:10 (forage type feedstuffs) to 40:40:20 (carbohydrate type feedstuffs).

Cellulolytic bacteria produce extracelluar cellulase and other enzymes that degrade cellulose and hemicellulose, first to oligosaccharides and then to glucose, glucose 6-phosphate, fructose 6-phosphate, and triosephosphates (Bergman 1990). Both noncellulolytic and cellulolytic organisms utilize the products of cellulose degradation directly to produce volatile fatty acids. Pectins and hemicellulose are first degraded to xylose and other pentoses. The major pathway of pentose utilization involves hexose

synthesis with the end products being fructose 6-phosphate and triosephosphates, as seen 
in cellulose fermentation. Starches and dextrans are degraded by amylases to maltose and further by maltases, with the end product being glucose 1-phosphate. All of the above hexoses and triosephosphates, however, are rarely detectable in ruminal or intestinal fluid because they undergo a rapid transformation to pyruvate through the Emben-Meyerhof pathway of glycolysis. Pyruvate, is then rapidly converted mostly to the more prominent volatile fatty acids (acetate, propionate, and butyrate), and, as a result, even pyruvate is not readily detectable in ruminal or intestinal fluids (Bergman 1990).

\section{Volatile Fatty Acids and Glucose Production}

In ruminants, carbohydrates in the feed are largely converted to volatile fatty acids as a result of microbial fermentation so that concentrations of blood glucose are lower than in monogastrics and vary little with feeding (De Jong, 1982). In ruminants, the liver must continually synthesize glucose to meet energy requirements for maintenance and lactation. Although propionate is a major glucose precursor in ruminants, gluconeogenesis from propionate is inadequate to provide all the glucose needed by extra-hepatic tissues (Bergman, 1975). Hepatic gluconeogenesis accounted for 87\% of glucose utilized in fed sheep (Bergman, 1975). In sheep fed near maintenance, over $80 \%$ of propionate absorbed from the portal blood was utilized for glucose synthesis (Steinhour and Bauman, 1988). In lactating dairy cows, even though over $90 \%$ of portal propionate was used by the liver for glucose production, hepatic propionate accounted for only about 55\% of hepatic glucose output (Reynolds et al., 1988).

Butyrate has been shown to be a potent inhibitor of glucose production from propionate (Aiello and Armentano, 1987; Looney et al., 1987) while acetate had no effect 
on glucose production from propionate (Aiello et al., 1989). Inhibition of glucose production from propionate by butyrate might have deleterious effects on glucose balance in lactating dairy animals because high producing dairy cattle are in a negative glucose state (Aiello et al., 1989). Faulkner and Pollock (1991) concluded that in lactating ruminants, major changes in glucose and ketone production were not the result of longterm changes within the hepatocyte, but occurred because of changes to the substrate supply and intracellular concentrations of metabolites. Net hepatic glucose release increased with increased hepatic propionate uptake and tended to increase with increased metabolized amino acid and lactate uptake (Lomax and Baird, 1983; Freetly and Ferrell, 1999).

\section{Liver Blood Flow and Volatile Fatty Acids}

Numerous researchers (Bergman and Wolff, 1971; Heitman et al., 1986; Burrin et al., 1989; Kristensen et al., 2000) have reported mean portal blood flow with ranges from 5.6 to $7.6 \mathrm{~L} \cdot \mathrm{h}^{-1} \cdot\left(\mathrm{BW}^{\cdot 75}\right)^{-1}$. Bensadoun and Reid (1962) demonstrated that hepatic arterial blood flow to the liver of ewes increases between 3 and 7 hours after feeding. Similarly, mean hepatic portal blood flow increased by about 45\% 3 hours after feeding (Katz and Bergman, 1969) and was influenced by the amount of energy in the diet (Parr et al., 1993b).

Ruminal infusion of volatile fatty acids increased hepatic portal blood flow (Sellers et al., 1964). Increasing concentrations of volatile fatty acids, decreasing $\mathrm{pH}$, and introducing carbon dioxide all increased blood flow from the rumen (Dobson and Phillipson, 1956). In sheep, ruminal infusion of propionate resulted in a 5-fold greater increase in ruminal arterial blood flow than an isoenergetic infusion of acetate (Sellers et 
al., 1964). This may have been a function of propionate sensors within the rumen wall that may elicit the increase in blood flow when energy increases (Wieghart et al., 1986). These sensors were triggered by increased propionate crossing the rumen wall (Wieghart et al., 1986). However, when volatile fatty acids were infused directly into the portal system, there was an increase in blood flow. Bensadoun and Reid (1962) hypothesized that the increased clearance of progesterone from ewes fed high-energy diets may be due to increased blood flow to the liver. Similarly, Sangsritavong et al. (2002) showed increased liver blood flow increased progesterone metabolism in both lactating and nonlactating dairy cattle.

\section{Insulin, Glucagon, and Volatile Fatty Acids Interaction}

Volatile fatty acids have the ability to stimulate insulin secretion from the pancreas (Harmon, 1992). Feeding diets with increased starch digestibility that increase the production of propionate, have led to increased secretion of insulin (Harmon, 1992). This stimulatory effect of volatile fatty acids on the pancreas is unique to ruminants (Horino et al., 1968; De Jong, 1982).

It has been shown that large doses of volatile fatty acids caused not only the release of insulin, but glucagon as well (Bassett, 1972; Elliot, 1980). In sheep, intravenous administration of either propionate or butyrate stimulated the secretion of both glucagon and insulin (Manns and Boda, 1967; Horino et al., 1968). Further, Manns et al. (1967) demonstrated that intravenous administration of propionate, butyrate or valerate increased insulin secretion. However, other researchers have not shown an increase in glucagon secretion. An intravenous administration of a physiological dose of acetate increased plasma insulin secretion but did not alter glucagon secretion (Mineo et 
al., 1990). Similarly, Sano et al. (1995) showed an intravenous injection of butyrate increased plasma insulin concentrations but did not affect glucagon concentrations.

When volatile fatty acids were infused directly into the rumen, some researchers have not seen an increase in the secretion of insulin and glucagon. Stern et al. (1970) showed that doubling ruminal propionate by intraruminal infusion did not change the concentrations of insulin in the jugular vein. However, De Jong (1982) saw an increase in insulin and glucagon following direct portal infusion of high doses of volatile fatty acids in the goat. When a constant physiological dose of propionate was infused directly into the rumen for 4 hours, there was a small increase in insulin but not glucagon (De Jong, 1982).

In the ruminant, acetate is the major circulating form of energy in the fed state (De Jong, 1982). Acetate utilization is dependent on insulin (Baile and Mayer, 1967; Skarda and Bartos, 1969; Yang and Baldwin, 1973; Schwalm and Schultz, 1976). Researchers have shown no increase in the secretion of insulin following an oral gavage of acetate in sheep (Manns and Boda, 1967; Trenkle, 1970), goats (De Jong, 1982), and cattle (McAtee and Trenkle, 1971).

It has been hypothesized that volatile fatty acids acted directly on the $\alpha$ and $\beta$ cells of pancreatic islets of Langerhans. Glucagon may be an intermediary between volatile fatty acids and insulin secretion, because glucagon was a potent stimulator of insulin (Bassett, 1971; Samols et al., 1972). Bassett (1972) reported that glucagon secretion increases coincident with insulin in sheep. It has been hypothesized that the initial post prandial increase in volatile fatty acids is a signal to secrete insulin and 
glucagon but ultimately concentrations of blood glucose would attenuate the secretion of insulin and glucagon (Grodsky, 1972).

\section{Insulin}

Single chain proinsulin is synthesized in the rough endoplasmic reticulum, presumably on membrane-bound polyribosomes, and transformed within the islet cells to insulin, the main storage product of the $\beta$ granules (Steiner et al., 1967; Steiner, 1967; Steiner et al., 1970; Sorensen et al., 1970). The subcellular site at which proinsulin is transformed to insulin was localized to the golgi apparatus and/or the newly formed secretory granules (Steiner et al., 1970; Kemmler and Steiner, 1970). The proteolytic conversion of proinsulin to insulin was a relatively slow process (on the order of hours), as shown by steady-state or pulse-chase labeling experiments (Steiner, 1967).

Although pancreatic $\beta$ cells are usually thought of as functioning in a synchronous manner, there is evidence of heterogeneity of both structure and function (Sando et al., 1972). For example, $\beta$ cells in the center of the islet core were more degranulated after a glucose challenge than $\beta$ cells in the periphery of the islet (Stefan et al., 1987). There are several studies that showed that the thresholds for glucose stimulation of insulin secretion and biosynthesis vary considerably among $\beta$ cells (Salomon and Meda, 1986; Schuit et al., 1988). There is evidence that stimulated $\beta$ cells of the dorsal lobe release more insulin than those in the ventral lobe (Weir and Weir, 1990). Virtually nothing is known about the mechanisms that underlie this heterogeneity. Presumably, some of the differences result from variations in the local environment and some are intrinsic to the cells (Weir and Weir, 1990). 
Selvaraju et al. (2002) found in cattle treated with insulin, circulating concentrations of progesterone significantly increased. Estrogen and other steroids have been shown to stimulate the expression of insulin messenger RNA and secretion from the $\beta$ cells in the pancreas (Morimoto, et al., 2001). Follicular estradial-17 $\beta$ is dependent on luteinizing hormone stimulated androgen production from thecal cells, which is enhanced by insulin and insulin-like growth factor-1 (Stewart et al., 1996). Reduced concentrations of insulin led to reduced androgen and estradial production and reduced the expression of luteinizing hormone receptors in the follicle (Diskin et al., 2003). Therefore, it is possible that dietary manipulations cause changes in pancreatic sensitivity to estrogen (Armstrong, et al., 2003).

Bovine granulosa cell cultures were dependent on physiological concentrations of insulin (Gutierrez, et al., 1997; Glister, et al., 2001). Armstrong, et al. (2001), showed that circulating concentrations of insulin changed during the estrous cycle and significantly increased with ovulation. The precise mechanism that regulated the increased concentration of insulin is not known. However, estrogen is a prime candidate as increased concentrations of estrogen paralleled increased concentrations of insulin (Armstrong, et al., 2003).

Numerous researchers have shown that dietary restriction and negative energy balance reduced circulating concentrations of insulin (Mackey et al., 1999; Sinclair et al., 2000). Not only does insulin play a role in carbohydrate metabolism; it also serves as a metabolic signal influencing luteinizing hormone release by the anterior pituitary (Monget and Martin, 1997), and plays a role in regulating ovarian sensitivity to gonadotropin. In the post-partum anestrous beef cow, ovulation of the dominant follicle 
did not occur when there were low circulating concentrations of insulin (Sinclair et al., 2000). Gong et al (2002a; 2002b) showed that cows fed a diet to increase circulating concentrations of insulin during the first 50 days post-partum had a shorter post-partum anestrous without affecting milk yield. In cattle, insulin is an important signal that mediates changes in nutrient intake associated with follicular dynamics. Insulin infused into energy deprived beef heifers caused an increase in the diameter of the dominant follicle (Simpson et al., 1994) and increased ovulation rate (Harrison and Randel, 1986). Dairy cattle selected for milk yield had lower circulating insulin (Armstrong et al., 2003). The feeding of diets designed to increase concentrations of insulin can advance the interval to first ovulation following parturition (Gong et al., 2002).

\section{Glucagon}

Tissue-specific post-translational processing of proglucagon results in the production of a diversity of peptides from the pancreas and intestine. Glucagon is the major product in the $\alpha$ cell of the pancreas, whereas glicentin, oxyntomodulin, glucagonlike peptide-1 and glucagon-like peptide -2 are the proglucagon -derived peptides produced in the intestine (Gutniak et al., 1992; Nathan et al., 1992).

Glucagon is an important factor in glucose and ketone metabolism, and its secretion is strongly influenced by changes in plasma glucose concentration (as reviewed by Weir and Weir, 1990). Normally, an increase in glucose concentration suppresses glucagon secretion while simultaneously stimulating insulin secretion. It is not known how much of the glucose effect is exerted directly upon the pancreatic $\alpha$ cell and how much is exerted indirectly through other islet cells and/or the autonomic nervous system (Weir and Weir, 1990). It has been difficult to elucidate because effects of $\beta$ and $\delta$ cells 
and the autonomic nervous system and the numerous intraislet interactions must be controlled to determine direct effects of $\alpha$ cells (Weir and Weir, 1990). Compared to insulin, relatively few in vitro studies have investigated the secretion of pancreatic glucagon. In isolated islet systems (Buchanan et al., 1969; Chesney and Schofield, 1969; Stagner et al., 1980), high glucose concentrations inhibited glucagon release. The mechanism of this action by glucose is not known, but glucose appeared to depress cytosolic concentrations of calcium in the $\alpha$ cells (Wang and McDaniel, 1990).

Some caution must be placed on in vitro research into islet function because pancreozymin (an in vivo stimulator of glucagon) did not stimulate glucagon secretion, and none of these hormones (pancreozymin, secretin, gastrin) stimulated secretion of insulin in vitro (Weir and Weir, 1990). This is different from findings in vivo. One rather obvious explanation would be that the environment of the islets is altered radically and that the islets have become insensitive to hormone releasing stimuli during the isolation procedure (Weir and Weir, 1990).

Animals fed a glucagon-stimulating diet, which would be similar to an acetate treatment, had a reduced embryo survival, and a decrease in circulating concentrations of progesterone on days 4 and 5 post-conception and the concentration of plasma progesterone was found to be positively related to the number of fetuses carried by the ewe (Bassett et al., 1969).

\section{Insulin and Glucagon Interactions}

Not only do $\beta$ cells communicate within pancreatic islets, but there is also communication between the islets (Weir and Weir, 1990). Insulin and glucagon in 
plasma oscillate with a period of 12 to 15 minutes in normal men (Lang et al., 1979). These oscillation patterns have been demonstrated utilizing the isolated perfused canine pancreas (Stagner et al., 1980). The mechanism(s) by which pancreatic islets synchronize their activity are not understood, but there may be some kind of intrinsic neural coordination that persists even after nerves that supply the pancreas are severed (Weir and Weir, 1990). These oscillations have been suggested to provide greater efficiency of insulin and glucagon action upon the liver by exposing the liver to both hormones simultaneously or alternatively (O’Rahilly et al., 1988).

Pancreatic glucagon has been reported to be a potent stimulator of insulin secretion in vivo (Samols et al., 1965; Ketterer et al., 1967) as well as in vitro (Turner and McIntyre, 1966; Iversen, 1970; Curry, 1970). Pancreatic glucagon stimulation of insulin secretion in vivo is not well understood. However, because of the rapid catabolism of peripheral concentrations of glucagon, to determine if pancreatic glucagon is insulinogenic in vivo, the potential stimulatory effect of glucagon must be measured locally before it is released into the peripheral system (Iversen, 1971). 


\section{STATEMENT OF THE PROBLEM}

In the livestock and dairy industries, significant cost and time is associated with the effort to maintain pregnancy. Further, the cost associated with having females remain open, especially in the dairy industry, contributes significantly to operating cost as well as increasing culling rates.

Early embryonic or fetal loss has been shown to be a major contributor to the low reproductive efficiency seen in the livestock and dairy industries. As previously discussed in the literature review, low circulating concentrations of progesterone can impact embryo survival. Further, it has been demonstrated that nutrition can alter the concentration of progesterone. Especially in the dairy industry, where animals are fed to optimize milk production, little emphasis is placed on the regulation of reproductive function and possible nutritional factors that may be less than optimal for embryonic or fetal survival.

Certainly, numerous factors contribute to embryonic or fetal loss; however, numerous researchers have shown that the circulating concentration of progesterone is a valuable indicator of potential embryonic or fetal loss. Given, the apparent importance of concentrations of progesterone, a more in-depth understanding of progesterone catabolism is warranted.

Progesterone is catabolized mainly by liver cytochrome P450 enzymes. Therefore, altering nutritional components of the diet, which alter the metabolic rate of the liver, might alter the catabolism of progesterone. These alterations in the catabolism of progesterone may significantly impact circulating concentrations of progesterone and thus influence the potential for embryo survival. 
Finally, if components of the diet could be substituted, that would allow for optimal production, without compromising reproductive efficiency, the livestock and especially the dairy industry would benefit. This benefit could contribute to the efficiency and sustainability of the livestock and dairy industries. 


\section{EFFECT OF ACETATE OR PROPIONATE ON THE CLEARANCE OF PROGESTERONE IN THE SHEEP}

\section{Abstract}

The objective of this experiment was to determine if an increase in the amount of acetate or propionate in hepatic portal blood, draining the gastrointestinal tract, could alter the metabolism of progesterone by the liver. In a preliminary study, four crossbred ewe lambs (BW $45.5 \pm 2.5 \mathrm{~kg}$ ) fed for maintenance and given a once daily oral gavage (0.146 $\mathrm{Mcal} / \mathrm{d})$ of acetate ( 0.7 moles) or propionate $(0.4$ moles) for $11 \mathrm{~d}$. Two $\mathrm{d}$ prior to the acclimation period, a portal-vein catheter was inserted, on d 12 post acclimation, portal and jugular venous blood were collected simultaneously $(-0.5,0,1,2,3,4,5,6,7 \mathrm{~h}$ with respect to feeding and volatile fatty acid gavage) and serum was analyzed for concentrations of volatile fatty acids by gas-liquid chromatography. The main experiment utilized 30 crossbred ewe lambs (BW $45.2 \pm 1.9 \mathrm{~kg}$ ) blocked by body weight and fed for maintenance for $11 \mathrm{~d}$. On d 12, each lamb was assigned randomly to one of two treatments, an oral gavage $(0.146 \mathrm{Mcal} / \mathrm{d})$ of either acetate $(0.7$ moles $)$ or propionate (0.4 moles). Animals received (i.m.) $20 \mathrm{mg}$ progesterone in corn oil. Plasma samples were collected $(-0.5,0.5,1,2,3,4,5,6,8 \mathrm{~h}$ relative to feeding, volatile fatty acid gavage, and progesterone injection) via jugular venipuncture and concentrations of progesterone were determined by radioimmunoassay. An oral gavage of acetate or propionate caused a marked change in the portal vein acetate or propionate concentrations for at least $4 \mathrm{~h}$. By $24 \mathrm{~h}$ after the oral gavage, the concentrations of acetate and propionate returned to baseline. Serum concentrations of progesterone after the oral gavage of either acetate or propionate began to increase as early as $0.5 \mathrm{~h}$ and were different $(\mathrm{P}<0.05)$ at $3 \mathrm{~h}(1.09 \pm$ $0.09 \mathrm{ng} / \mathrm{ml}$ vs. $2.04 \pm 0.48 \mathrm{ng} / \mathrm{ml})$ and $4 \mathrm{~h}(1.20 \pm 0.09 \mathrm{ng} / \mathrm{ml}$ vs. $1.95 \pm 0.41 \mathrm{ng} / \mathrm{ml})$ for 
ewe lambs orally-gavaged with acetate or propionate, respectively. By 5 h, coincident with the return to baseline portal vein acetate or propionate concentrations following an oral gavage, concentrations of progesterone were not different. Increased portal vein concentrations of propionate reduced the clearance of progesterone.

Key Words: Progesterone, Acetate, Propionate, Liver Metabolism, Sheep. 


\section{Introduction}

In sheep, plasma progesterone increases from 2 to $3 \mathrm{ng} / \mathrm{ml}$ in early pregnancy to approximately 10 to $20 \mathrm{ng} / \mathrm{ml}$ on d 130 to 140 of gestation and falls to $1 \mathrm{ng} / \mathrm{ml}$ at parturition (Bassett et al., 1969). Further, at least $2 \mathrm{ng} / \mathrm{ml}$ of progesterone were necessary for a normal conception rate (Parr et al., 1987). Increasing the clearance of progesterone may decrease peripheral concentrations of progesterone below the threshold necessary for embryo survival (Parr, 1992; O’Callaghan et al., 2000).

The liver accounts for the majority of progesterone clearance. In a number of experiments in which different energy intakes were used to modify the clearance of progesterone in sheep, dry matter intake has been confounded with metabolizable energy (as reviewed by Parr, 1992). Rates of blood flow in the portal vein are related directly to the level of feeding (Bensadoun and Reid, 1962). Variation in the quality and physical form of the diets, given equal nutrient densities, had no apparent effect on portal blood flow (Webster, et al., 1975). However, ruminal infusion of propionate, or butyrate increased rumen arterial blood flow five times more than an isoenergetic infusion of acetate (Sellers et al., 1964).

We hypothesized that changing the form of energy while balancing for dry matter intake and metabolizable energy will alter the clearance of progesterone from circulation. The objectives of these experiments were to: 1 ) Determine the hepatic portal vein acetate and propionate concentrations after a single, oral gavage of acetate or propionate, and 2) Determine the effect of a single oral gavage of acetate or propionate on the rate of progesterone clearance. 


\section{Materials and Methods}

\section{Preliminary Study}

All procedures and protocols involving the use of animals were approved by the West Virginia University Animal Care and Use Committee (ACUC \#02-1204). Four crossbred, yearling ewe lambs (BW $45.5 \pm 2.5 \mathrm{~kg}$ ) were housed in individual (2.1 m x 2.1 m) pens. Lambs were fed grass hay at 2\% of BW (\%DM 89.2, \%CP 9.2, \%TDN 53.9) to meet NRC (1985) maintenance requirements (once daily at 0800). Water was provided ad libitum throughout the acclimation and experimental period. The lambs were assigned randomly to one of two treatments, a once daily oral gavage of 0.7 mole acetate in $200 \mathrm{ml}$ $\mathrm{H}_{2} \mathrm{O}$ (sodium acetate, Lot 81K0206, Sigma Chemical Co., St Louis, Mo); or 0.4 mole propionate in $200 \mathrm{ml} \mathrm{H}_{2} \mathrm{O}$ (sodium propionate, Lot 021K0158, Sigma Chemical Co., St Louis, Mo); for an 11-d acclimation period. The orally-gavaged energy content (0.146 Mcal) was equal between the acetate and propionate treatments and represents approximately $10 \%$ of the ewe lamb’s daily energy requirement (NRC, 1985).

Prior to the acclimation period, all lambs were determined to be anestrous, defined by serum concentrations of progesterone $<0.7 \mathrm{ng} / \mathrm{ml}$ for two-blood samplings $6 \mathrm{~d}$ apart (-7 and -1 d). A portal vein catheter was inserted in each lamb according to the method of Ferrell et al. (1992). Following induction and maintenance of anesthesia, a paracostal incision $(\sim 34 \mathrm{~cm})$ was made parallel to and $5 \mathrm{~cm}$ posterior to the last rib. A hole was punctured in the portal vein approximately $8 \mathrm{~cm}$ from the liver utilizing a 14-g needle and a heparinized (TDMAC heparin complex, Lot 73733; Polyscience Inc., Warrington, PA) catheter (ID 1.0 mm, OD 1.8 mm, Lot 50466, Cole-Parmer Instrument Co., Vernon Hills, IL) was inserted $(\sim 6 \mathrm{~cm})$ until the tip was at the liver. A purse-string 
suture was tied around the catheter to secure it inside the portal vein. The catheter was sutured to the portal lymph node to further stabilize its placement. The free end of the catheter was tunneled under the skin using a trocar and exteriorized near the middle of the back. Catheter patency was confirmed, the catheter was filled with heparinized saline (100 i.u./ml heparin, $150 \mathrm{mM} \mathrm{NaCl}$ ) and tied off. One animal assigned to acetate treatment lost portal vein catheter patency prior to blood sampling and was removed from the experiment.

On d 12 after the start of the acclimation period, $3 \mathrm{ml}$ samples of portal and jugular venous blood were collected simultaneously at frequent intervals $(-0.5,0,1,2,3$, 4, 5, 6, $7 \mathrm{~h}$ ) with respect to feeding and the oral-gavage of volatile fatty acid. Blood was combined with $100 \mu \mathrm{l}$ of heparinized saline, stored at $4^{\circ} \mathrm{C}$ for less than $4 \mathrm{~h}$ until spun at $3000 \mathrm{~g}$ for $15 \mathrm{~min}$ and the plasma was aspirated and frozen until assayed for concentrations of volatile fatty acids. To determine the acetate and propionate concentrations for the feed alone, $\mathrm{d} 13$ samples were collected in a similar manner as $\mathrm{d}$ 12, except acetate and propionate were not orally-gavaged.

Plasma (1 ml) was extracted with $5 \mathrm{ml}$ of $100 \%$ ethanol, the precipitate was removed by centrifugation and the supernatant was mixed with $100 \mu$ l sodium hydroxide (0.2 M) and air dried. The dry residue was reconstituted in $20 \mu \mathrm{l}$ of $30 \mathrm{mM}$ oxalic acid and $1 \mu \mathrm{l}$ of the reconstituted sample was injected onto a $2 \mathrm{~m}$ x $2 \mathrm{~mm}$ I.D. glass column (80/120 Carbopack B-DA/4\% Carbowax 20M, Supelco Inc., Bellefonte, PA) and gasliquid chromatography (Varian 3300 Gas Chromatograph, Varian Inc, Walnut Creek, CA; Integrator: Varian 4290, Varian Inc, Walnut Creek, CA) was used to determine jugular and portal vein volatile fatty acid concentrations (Remesy and Demigne, 1974). 


\section{Experiment}

Thirty crossbred yearling anestrous ewe-lambs, 16 in replicate 1 and 14 in

replicate 2; (BW $45.2 \pm 1.9 \mathrm{~kg}$ ) were blocked by body weight and housed (3 x 3 m pens) two ewe-lambs per pen. Within each pen, each lamb was assigned randomly to one of two treatments, either an oral gavage of acetate or propionate as in preliminary experiment. Lambs were fed grass hay at 2\% of body weight (\%DM 89.2, \%CP 9.2, \%TDN 53.9) to meet NRC (1985) maintenance requirements (once daily at 0700), for an 11-d acclimation period. Water was provided ad libitum throughout the acclimation and experimental period. All lambs were anestrus, defined as serum concentrations of progesterone $<0.7 \mathrm{ng} / \mathrm{ml}$ at both of two samplings $6 \mathrm{~d}$ apart.

On d 12, following the acclimation period, animals were injected (i.m.) with 20 mg progesterone (Lot 100K0204, Sigma Chemical Co., St Louis, Mo) in corn oil (20 $\mathrm{mg} / \mathrm{ml})$ and orally-gavaged with either acetate ( 0.7 moles) or propionate ( 0.4 moles) as in the preliminary study. Blood samples were collected via jugular venipuncture at -0.5 , $0.5,1,2,3,4,5,6$, and 8 h relative to feeding, volatile fatty acid gavage, and progesterone treatment. Blood was stored at $4^{\circ} \mathrm{C}$ for $24 \mathrm{~h}$, spun at $3000 \mathrm{~g}$ for $15 \mathrm{~min}$ and the serum was aspirated and frozen until assayed. Jugular serum concentrations of progesterone were determined by radioimmonoassay, with a sensitivity of $100 \mathrm{pg} / \mathrm{mL}$ and intra- and inter-assay CV 6.8 \% and $7.1 \%$, respectively (Sheffel et al., 1982).

\section{Statistical Analysis}

Statistical models included treatment effect (acetate versus propionate), time, replicate, and a treatment $\mathrm{x}$ time interaction in a randomized block design. Preliminary analysis showed no significant differences between replicates of the experiment, so the 
data were combined and analyzed together. The concentrations of progesterone were analyzed using PROC MIXED for repeated measures and means separation was performed using the LSMEANS procedure of SAS (SAS Inst., Inc., Cary, NC).

\section{Results}

\section{Preliminary Study}

A single oral gavage of acetate or propionate increased the portal vein acetate or propionate concentration for at least $4 \mathrm{~h}$ compared to feed alone (Figure 1 and 2). Further, by $24 \mathrm{~h}$ post-gavage, the portal vein acetate or propionate concentrations returned to the baseline concentrations as demonstrated by the beginning $(-0.05 \mathrm{~h})$ acetate and propionate concentrations on d 13 (feed alone). The concentrations of volatile fatty acids in the jugular vein relative to the oral gavage of volatile fatty acids are presented in Table 1. Following the propionate treatment, there was only a minimal increase in the concentration of propionate in the peripheral circulation whereas following the acetate treatment, peripheral concentrations of acetate increased dramatically (Table 1). Experiment

Serum concentrations of progesterone (Figure 3), after the oral gavage of either acetate or propionate, began to diverge as early $0.5 \mathrm{~h}$ and were different $(\mathrm{P}<0.05)$ at $3 \mathrm{~h}$ $(1.09 \pm 0.09 \mathrm{ng} / \mathrm{ml}$ vs. $2.04 \pm 0.48 \mathrm{ng} / \mathrm{ml})$ and $4 \mathrm{~h}(1.20 \pm 0.09 \mathrm{ng} / \mathrm{ml}$ vs. $1.95 \pm 0.41$ $\mathrm{ng} / \mathrm{ml}$ ) for ewe lambs orally-gavaged with acetate or propionate, respectively. By $5 \mathrm{~h}$, coincident with the return to baseline, portal vein acetate or propionate concentrations seen in Figures 1 and 2, circulating concentrations of progesterone were not different. 


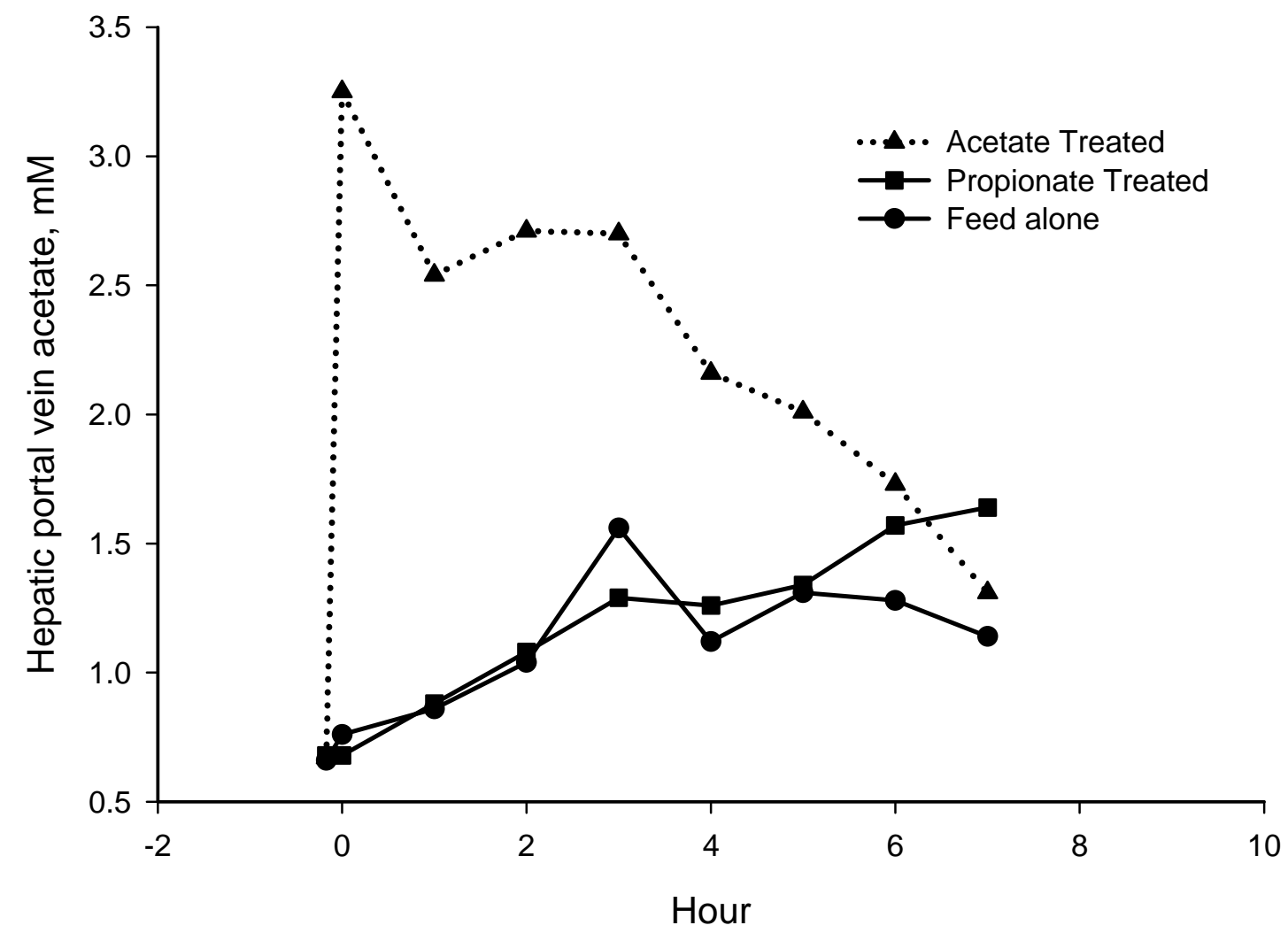

Figure 1: The hepatic portal vein concentration of acetate following feed alone or feed plus an oral gavage $(0.146 \mathrm{Mcal})$ of acetate or propionate. 


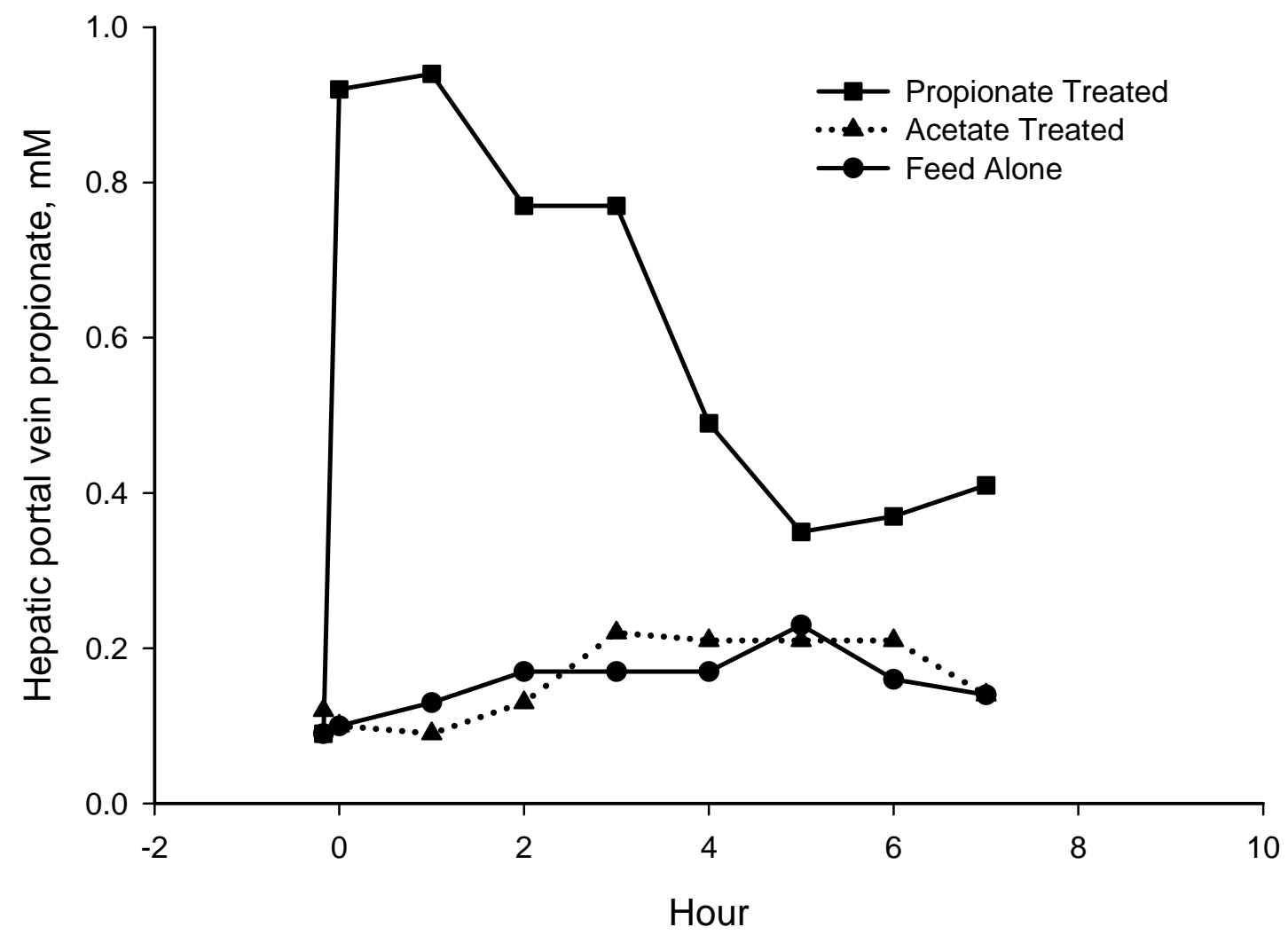

Figure 2: The hepatic portal vein concentration of propionate following feed alone or feed plus an oral gavage (0.146 Mcal) of acetate or propionate. 
Table 1: Concentrations of acetate and propionate (mM) in jugular vein plasma following feed alone or feed plus an oral gavage of $0.146 \mathrm{Mcal} / \mathrm{d}$ of acetate or propionate.

\begin{tabular}{|c|c|c|c|c|c|c|}
\hline \multirow[b]{2}{*}{$\underline{\text { Hour }}$} & \multicolumn{2}{|c|}{ Feed Alone } & \multicolumn{2}{|c|}{ Propionate Treatment } & \multicolumn{2}{|c|}{ Acetate Treatment } \\
\hline & Acetate & Propionate & Acetate & Propionate & Acetate & Propionate \\
\hline-0.05 & 0.31 & 0.02 & 0.29 & 0.07 & 0.60 & 0.03 \\
\hline 0 & 0.37 & 0.02 & 0.31 & 0.09 & 0.85 & 0.04 \\
\hline 1 & 0.43 & 0.02 & 0.32 & 0.09 & 0.80 & 0.03 \\
\hline 2 & 0.50 & 0.03 & 0.37 & 0.06 & 1.04 & 0.03 \\
\hline 3 & 0.49 & 0.03 & 0.37 & 0.04 & 1.00 & 0.03 \\
\hline 4 & 0.56 & 0.02 & 0.46 & 0.03 & 0.85 & 0.03 \\
\hline 5 & 0.55 & 0.02 & 0.46 & 0.03 & 0.80 & 0.02 \\
\hline 6 & 0.54 & 0.02 & 0.55 & 0.04 & 0.65 & 0.02 \\
\hline 7 & 0.59 & 0.02 & 0.49 & 0.04 & 0.65 & 0.03 \\
\hline
\end{tabular}




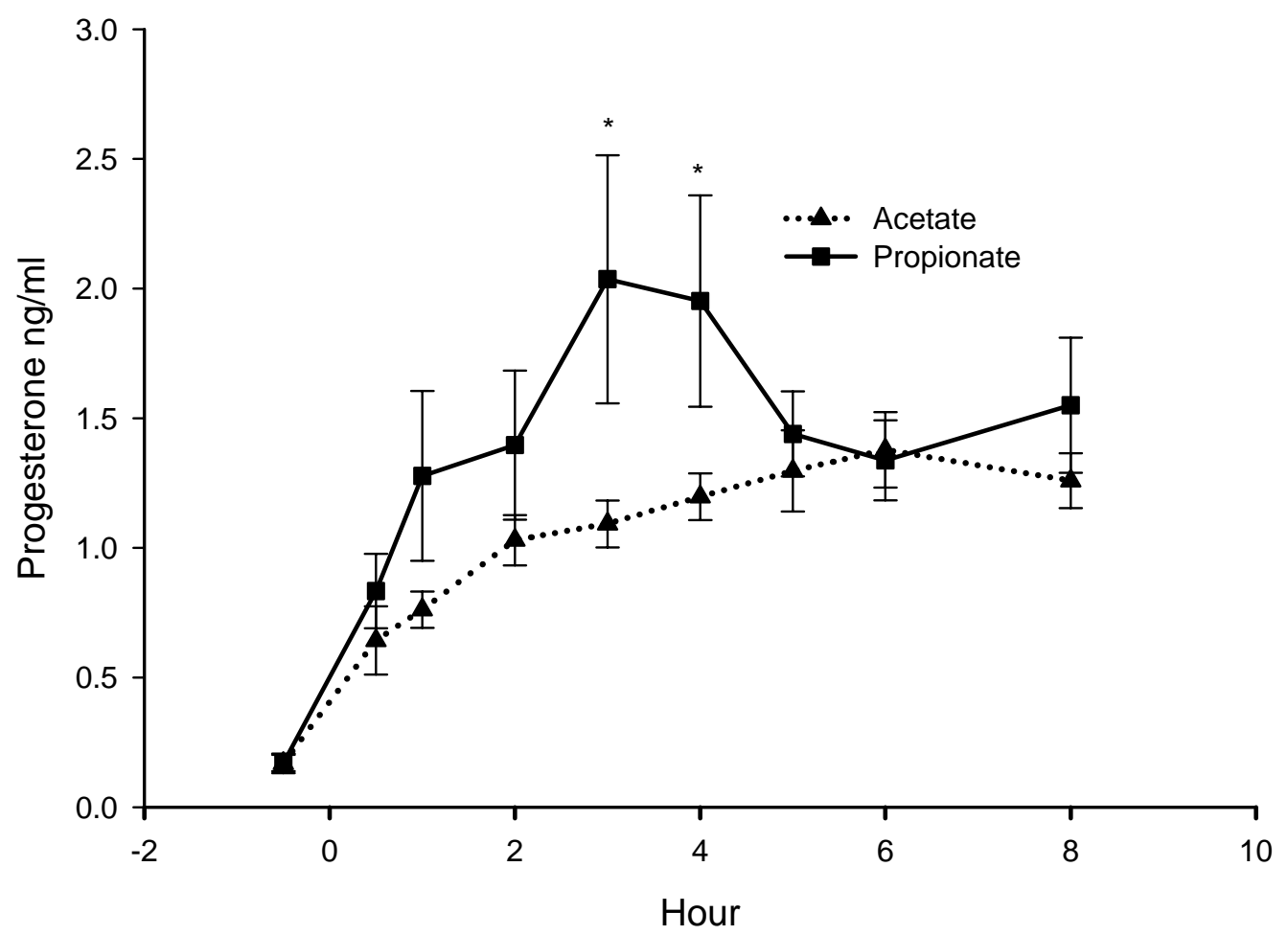

Figure 3: Concentration of serum progesterone (mean \pm SEM) following a single oral gavage $(0.146 \mathrm{Mcal})$ of acetate or propionate. Asterisks denote differences $(\mathrm{P}<0.05)$ between the acetate and propionate treatments. 


\section{Discussion}

An oral gavage of acetate or propionate resulted in different rates of clearance of progesterone. Peripheral concentrations of progesterone were elevated significantly in ewes consuming a diet meeting only $25 \%$ of their maintenance energy requirements (Cumming et al., 1971). Similarly, Parr et al. (1987) showed there was a decline in peripheral progesterone concentrations with increasing dietary energy. The differences in the metabolic clearance rate of progesterone between ewes fed below, versus in excess, of maintenance was significant (Parr et al., 1993a). Adams et al. (1994) showed a slower passage of digesta in restricted ewes, which was associated with an increase in the plasma concentration of hormone metabolites, which may in turn affect ovarian feedback. Further, Shevah et al. (1975) found no change in luteinizing hormone when ewes were fed either a below-maintenance diet versus a maintenance diet, resulting in greater concentrations of progesterone, or in excess of maintenance, resulting in lesser concentrations of progesterone. Similarly, Abecia et al. (1995) concluded that the embryo loss that occurs in a sheep fed a below-maintenance diet versus a maintenance diet was not a result of increased luteinizing hormone or an increase in the capacity of the corpus luteum to synthesize and release progesterone. Taken together, these observations support the suggestion that alterations in the diet alter the clearance, not the synthesis, of progesterone.

It has been shown that at least $2 \mathrm{ng} / \mathrm{ml}$ of progesterone is necessary for satisfactory conception rates (Parr et al., 1987). Ewes fed below their maintenance energy requirement had greater peripheral concentrations of progesterone, but on d 5 of the estrous cycle had lower endometrial concentrations of progesterone than ewes fed in 
excess of maintenance energy requirement (Lozano et al., 1998). Progesterone supplementation had no effect on ewes that were fed below-maintenance or maintenance diets, but in ewes fed the diet in excess of maintenance, progesterone supplementation increased the pregnancy rate from 48 to 76 \% (Parr et al., 1987). This led the authors to conclude that exogenous progesterone will increase pregnancy rate only in ewes fed in excess of maintenance or an increasing energy diet. The present data show that at equal energy and dry matter intake there are alterations in the clearance of progesterone as a result of the form of energy.

Bensadoun and Reid (1962) hypothesized that the increased clearance of progesterone from ewes fed high-energy diets may be due to increased blood flow to the liver. In this experiment, hepatic portal blood flow was not determined. However, numerous researchers (Bergman and Wolff, 1971; Heitman et al., 1986; Burrin et al., 1989; Kristensen et al., 2000) have reported mean portal blood flow with ranges from 5.6 to $7.6 \mathrm{~L} \cdot \mathrm{h}^{-1} \cdot\left(\mathrm{BW}^{\cdot 75}\right)^{-1}$. Bensadoun and Reid (1962) demonstrated that blood flow to the liver of ewes increased between 3 and $7 \mathrm{~h}$ after feeding. Similarly, mean hepatic blood flow increased by about 45\% 3 h after feeding (Katz and Bergman, 1969) and was influenced by the amount of energy in the diet (Parr et al., 1993b).

Less progesterone was cleared following the propionate than with the acetate gavage. Ruminal infusion of volatile fatty acids increased hepatic portal blood flow (Sellers et al., 1964). Increasing concentrations of volatile fatty acids, decreasing $\mathrm{pH}$, and introducing carbon dioxide all increased blood flow from the rumen (Dobson and Phillipson, 1956). In sheep, ruminal infusion of propionate resulted in a 5-fold greater increase in ruminal arterial blood flow than an isoenergetic infusion of acetate (Sellers et 
al., 1964). If blood flow was involved in the observed alteration in progesterone clearance, then one would expect that the likely greater increase in hepatic portal blood flow following the propionate gavage would have resulted in an increased rate of clearance. Instead the opposite occurred with progesterone clearance reduced following the propionate as compared to the acetate treatment.

Alterations in the type of feedstuffs or the physiological status of the ewe may play a greater role in embryo survival than previously thought. Further, progesterone clearance was altered without alterations in dry matter intake or energy, and likely without changes in hepatic portal blood flow from those observed in the literature. Further research is needed to determine the mechanism that results in alterations in clearance of progesterone. In this experiment, balancing dry matter intake and energy, while altering the volatile fatty acid profile leaving the rumen, resulted in alterations in the clearance of progesterone. Therefore, alterations in feedstuffs may influence clearance of progesterone and potentially affect pregnancy rate. 


\section{Literature Cited}

Abecia, J.A., S.M. Rhind, T.A. Bramley, and S.R. McMillen. 1995. Steroid production and LH receptor concentrations of ovarian follicles and corpora lutea and associated rates of ova wastage in ewes given high and low levels of food intake before and after mating. Anim. Sci. 61:57-62.

Adams, N.R., J.A. Abordi, J.R. Briegel, and M.R. Sanders. 1994. Effect of diet on the clearance rate of estradiol-17 $\beta$ in the ewe. Biol. Reprod. 51:668-674.

Bassett, J.M., T.J. Oxborrow, I.D. Smith, and G.D. Thorburn. 1969. The concentration of progesterone in the peripheral plasma of the pregnant ewe. J. Endocrinol. 45:449-457.

Bensadoun, A., and J.T. Reid. 1962. Estimation of rate of portal blood flow in ruminants: effect of feeding, fasting, and anesthesia. J. Dairy. Sci. 45:540-543.

Bergman, E.N., and J.E. Wolff. 1971. Metabolism of volatile fatty acids by liver and portal-drained viscera in sheep. Am. J. Physiol. 221:586-592.

Burrin, D.G., C.L. Ferrell, J.H. Eisemann, R.A. Britton, and J.A. Nienaber. 1989. Effect of level of nutrition on splanchnic blood flow and oxygen consumption in sheep. Br. J. Nutr. 62:23-34.

Cumming, I.A., B.J. Mole, J. Obst, M.A. de B. Blockey, C.G. Winfield, and J.R. Goding. 1971. Increase in plasma progesterone caused by undernutrition during early pregnancy in the ewe. J. Reprod. Fert. 24:146-147.

Dobson, A., and A.T. Phillipson. 1956. The influence of the contents of the rumen and of adrenaline upon its blood supply. J. Physiol. 133:76-77.

Ferrell, C.L., R.A. Britton, and H.C. Freetly. 1992. Chronic catheterization of portal and hepatic veins in sheep. In: P.J. Dziuk and M.B. Wheeler (Ed.) Handbook of Methods for Study of Reproductive Physiology of Domestic Animals. Dept. of Animal Science, Univ. of Illinois, Urbana.

Heitmann, R.N., S.C. Sensenig, C.K. Reynolds, J.M. Fernandez, and D.J. Dawes. 1986. Changes in energy metabolite and regulatory hormone concentrations and net fluxes across splanchnic and peripheral tissues in fed and progressively fasted ewes. J. Nutr. 116: 2516-2524.

Katz, M.L., and E.N. Bergman. 1969. Simultaneous measurements of hepatic and portal venous blood flow in the sheep and dog. Am. J. Physiol. 216:946-952.

Kristensen, N.B., S.G. Pierzynowski, and A. Danfaer. 2000. Net portal appearance of volatile fatty acids in sheep intraruminally infused with mixtures of acetate, propionate, isobutyrate, and valerate. J. Anim. Sci. 78:1372-1379. 
Lozano, J.M., J.A. Abecia, F. Forcada, L. Zarazaga, and B. Alfaro. 1998. Effect of undernutrition on the distribution of progesterone in the uterus of ewes during the luteal phase of the estrous cycle. Theriogenology. 49:539-546.

NRC. 1985. Pages 2-25 in Nutrient Requirements of Sheep, $6^{\text {th }}$ rev. ed. Natl. Acad. Press, Washington, DC.

O’Callaghan, D., H. Yaakub, P. Hyttel, L.J. Spicer, and M.P. Boland. 2000. Effect of nutrition and superovulation on oocyte morphology, follicular fluid composition and systemic hormone concentrations in ewes. J. Reprod. Fertil. 118:303-313.

Parr, R.A., I.F. Davis, R.J. Fairclough, and M.A. Miles. 1987. Overfeeding during early pregnancy reduces peripheral progesterone concentration and pregnancy rate in sheep. Reprod. Fert. 80:317-320.

Parr, R.A. 1992. Nutrition-progesterone interactions during early pregnancy in sheep. Reprod. Fert. Dev. 4:297-300.

Parr, R.A., I.F. Davis, M.A. Miles, and T.J. Squires. 1993a. Feed intake affects metabolic clearance rate of progesterone in sheep. Res. Vet. Sci. 55:306-310.

Parr, R.A., I.F. Davis, M.A. Miles, and T.J. Squires. 1993b. Liver blood flow and metabolic clearance rate of progesterone in sheep. Res. Vet. Sci. 55:311-316.

Remesy, C. and C. Demigne. 1974. Determination of volatile fatty acids in plasma after ethanolic extraction. Biochem J. 141:85-91.

Sellers, A.F., C.E. Stevens, A. Dobson, and F.D. McLeod. 1964. Arterial blood flow to the ruminant stomach. Am. J. Physiol. 207:371-377.

Sheffel, C.E., B.R. Pratt, W.L. Ferrell and E.K. Inskeep. 1982. Induced corpora lutea in the postpartum beef cow. II. Effects of treatment with progestogen and gonadotropins. J. Anim. Sci. 54:830-836.

Shevah, Y., W.J.M. Black, W.R. Carr, and R.B. Land. 1975. The effects of nutrition on the reproductive performance of Finn x Dorset ewes. J. Reprod. Fert. 45:283-288.

Webster, A.J., P.O. Osuji, F. White, and J.F. Ingram. 1975. The influence of food intake on portal blood flow and heat production in the digestive tract of sheep. Br. J. Nutr. 34:125-139. 


\section{EFFECT OF ACETATE OR PROPIONATE ON CIRCULATING CONCENTRATIONS OF INSULIN OR GLUCAGON IN THE EWE}

\section{Abstract}

The objective of this experiment was to determine the effect of a single oral gavage of either acetate or propionate on peripheral concentrations of insulin and glucagon in the ewe. Five crossbred yearling anestrous ewes (55.6 $\pm 1.4 \mathrm{~kg})$ were fed for maintenance for an 11-d acclimation period. On d 12, following the acclimation period, animals were orally-gavaged with either acetate $(0.7$ moles $)$ or propionate $(0.4$ moles $)$. On d 17 , each pen was treated again with acetate or propionate in a switchback design. Blood samples were collected via jugular venipuncture at $-0.5,0.5,1,2,3,4,5,6$, and 8 h relative to feeding and volatile fatty acid gavage. Blood was assayed for concentrations of glucagon and insulin. Serum concentrations of insulin after an oral gavage of either acetate or propionate, were different $(\mathrm{P}<0.05)$ at $0.5 \mathrm{~h}(0.14 \pm 0.04 \mathrm{nM}$ vs. $0.63 \pm 0.08 \mathrm{nM})$ and 1 $\mathrm{h}(0.12 \pm 0.04 \mathrm{nM}$ vs. $0.23 \pm 0.04 \mathrm{nM})$ for ewe lambs orally-gavaged with acetate and propionate, respectively. Further, serum concentrations of glucagon after an oral gavage of either acetate or propionate, were different $(\mathrm{P}<0.05)$ at $0.5 \mathrm{~h}(0.019 \pm 0.002 \mathrm{nM}$ vs. $0.048 \pm 0.007 \mathrm{nM}), 1 \mathrm{~h}(0.021 \pm 0.004 \mathrm{nM}$ vs. $0.041 \pm 0.006 \mathrm{nM})$ and $2 \mathrm{~h}(0.016 \pm 0.003$ nM vs. $0.033 \pm 0.006 \mathrm{nM}$ ) for ewe lambs orally-gavaged with acetate and propionate, respectively. Rations that stimulate the production of propionate, increasing the portalvein propionate concentration, may alter insulin and glucagon secretion.

KEY WORDS: Insulin, Glucagon, Acetate, Propionate, Sheep 


\section{Introduction}

In ruminants, carbohydrates in the feed are largely converted to volatile fatty acids as a result of microbial fermentation so that concentrations of blood glucose vary little with feeding (De Jong, 1982). Volatile fatty acids stimulate insulin secretion from the pancreas (Harmon, 1992), a phenomenon unique to ruminants (Horino et al., 1968; De Jong, 1982).

Feeding diets with increased starch digestibility or increasing the proportion of propionate through feed grade propionate have led to increased secretion of insulin (Harmon, 1992). It has been shown that large pharmacological doses of volatile fatty acids caused not only the release of insulin, but glucagon as well (Bassett, 1972; Elliot, 1980). In sheep, intravenous administration of either propionate or butyrate stimulated the secretion of both glucagon and insulin (Manns and Boda, 1967; Horino et al., 1968). Further, Manns et al. (1967) demonstrated that intravenous administration of propionate, butyrate or valerate increased insulin secretion. However, an intravenous administration of a physiological dose of acetate increased plasma insulin secretion but did not alter glucagon secretion (Mineo et al., 1990). Similarly, Sano et al. (1995) showed that an intravenous injection of butyrate increased plasma insulin concentrations but did not affect glucagon concentrations.

Stern et al. (1970) showed that doubling ruminal propionate by intraruminal infusion did not change the concentrations of insulin in the jugular vein. However, De Jong, (1982) saw an increase in insulin and glucagon following direct portal infusion of high doses of volatile fatty acids in the goat. When a constant physiological dose of 
propionate was infused directly into the rumen for $4 \mathrm{~h}$, there was a small increase in insulin but not glucagon (De Jong, 1982).

The objective of this experiment was to determine the effect of a single oral gavage of either acetate or propionate on peripheral concentrations of insulin and glucagon in the ewe. 


\section{Materials and Methods}

All procedures and protocols involving the use of animals were approved by the West Virginia University Animal Care and Use Committee (ACUC \#04-0604). Five crossbred yearling anestrous ewe-lambs (55.6 $\pm 1.37 \mathrm{~kg})$, were housed in 3 x $3 \mathrm{~m}$ pens; two ewe-lambs in one pen and three ewe-lambs in an adjacent pen. Lambs were fed grass hay at $2 \%$ of body weight (\%DM 90.6, \%CP 14.7, \%TDN 64.8) to meet NRC (1985) maintenance requirements (once daily at 0700), for an 11-d acclimation period. Water was provided ad libitum throughout the acclimation and experimental period.

On d 12, following the acclimation period, animals were orally-gavaged with either acetate ( 0.7 moles) or propionate ( 0.4 moles). Each pen was assigned to one of two treatments, an oral gavage of 0.7 mole acetate in $200 \mathrm{ml} \mathrm{H}_{2} \mathrm{O}$ (sodium acetate, Lot 81K0206, Sigma ${ }^{\circledR}$ Chemical Co., St Louis, Mo); or 0.4 mole propionate in $200 \mathrm{ml} \mathrm{H}_{2} \mathrm{O}$ (sodium propionate, Lot 021K0158, Sigma Chemical Co., St Louis, Mo). The orallygavaged energy content $(0.146 \mathrm{Mcal})$ was equal between the acetate and propionate treatments and represented approximately $10 \%$ of the ewe lamb's daily energy requirement (NRC, 1985). Again, on d 17 each pen was treated alternatively with acetate or propionate in a switchback design. Blood samples were collected via jugular venipuncture at $-0.5,0.5,1,2,3,4,5,6,8 \mathrm{~h}$ relative to feeding and volatile fatty acid gavage. Blood was combined with $100 \mu \mathrm{l}$ of heparinized saline, stored at $4^{\circ} \mathrm{C}$ for less than $1 \mathrm{~h}$ until centrifuged at $3000 \mathrm{~g}$ for $15 \mathrm{~min}$ and the plasma aspirated and frozen until assayed for concentrations of glucagon (double antibody glucagon radioimmunoassay, Lot 0021, Diagnostic Products Corporation, Los Angeles, CA) and insulin (insulin enzyme-linked immuno-sorbent assay, Lot 05264, Diagnostic Systems Laboratories, Inc., 
Webster, TX), according to the manufacturers' instructions. The assays had a sensitivity of $13 \mathrm{pg} / \mathrm{mL}$ and intra- and inter-assay CV of $5.5 \%$ and $9.1 \%$ for glucagon and a sensitivity of $1 \mathrm{ng} / \mathrm{mL}$ and intra- and inter-assay CV of $4.5 \%$ and $6.5 \%$ for insulin. Statistical Analysis

Statistical models included treatment effect (acetate or propionate), time, and a treatment $\mathrm{x}$ time interaction in a crossover design. The circulating concentrations of insulin (cube root transformed) and glucagon (log transformed) were analyzed using the GLM T-TEST procedure of SAS (SAS Inst., Inc., Cary, NC).

\section{Results}

Serum concentrations of insulin for ewe lambs (Figure 4), after an oral gavage of either acetate or propionate, were different $(\mathrm{P}<0.05)$ at $0.5 \mathrm{~h}(0.14 \pm 0.04 \mathrm{nM}$ vs. $0.63 \pm$ $0.08 \mathrm{nM})$ and $1 \mathrm{~h}(0.12 \pm 0.04 \mathrm{nM}$ vs. $0.23 \pm 0.04 \mathrm{nM})$, respectively. Serum concentrations of glucagon (Figure 5), were different $(\mathrm{P}<0.05)$ at $0.5 \mathrm{~h}(0.019 \pm 0.002$ nM vs. $0.048 \pm 0.007 \mathrm{nM}), 1 \mathrm{~h}(0.021 \pm 0.004 \mathrm{nM}$ vs. $0.041 \pm 0.006 \mathrm{nM})$ and $2 \mathrm{~h}(0.016$ $\pm 0.003 \mathrm{nM}$ vs. $0.033 \pm 0.006 \mathrm{nM}$ ) after ewe lambs were orally-gavaged with acetate or propionate, respectively. 


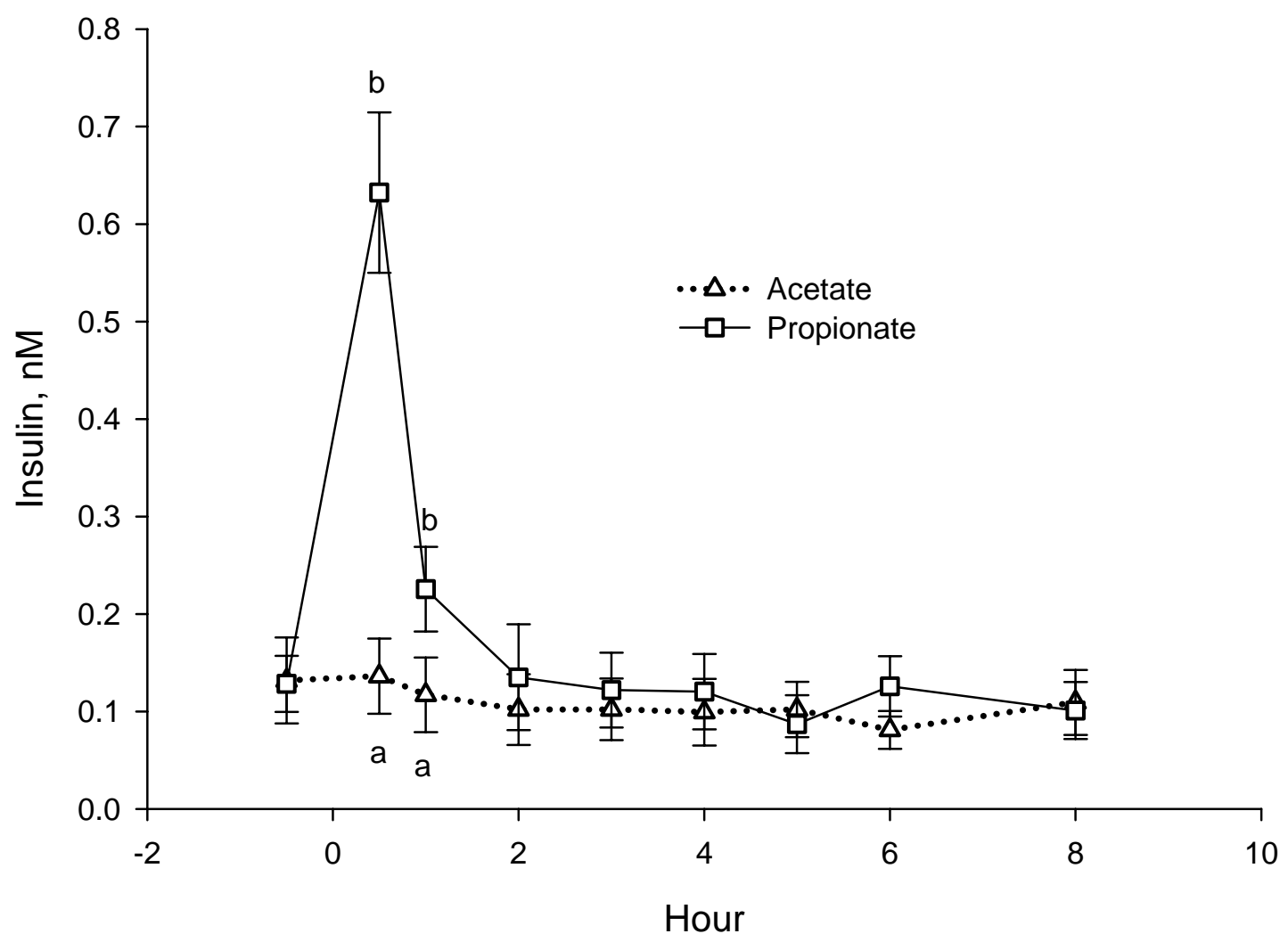

Figure 4: The jugular vein concentration of insulin following an oral gavage (0.146 Mcal) of acetate or propionate. Means \pm SEM with different letters differ $(\mathrm{P}<0.05)$. 


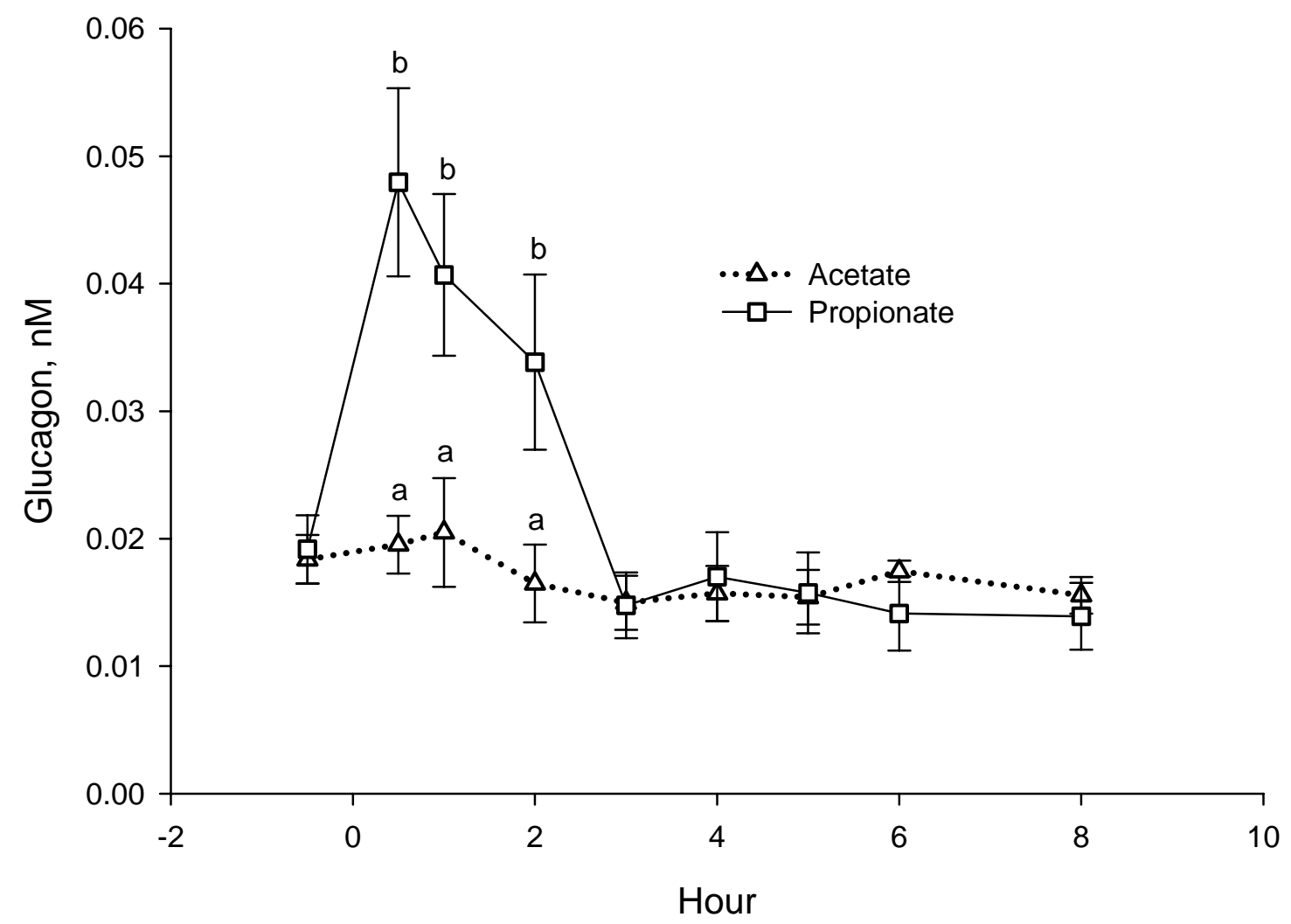

Figure 5: The jugular vein concentration of glucagon following an oral gavage (0.146 Mcal) of acetate or propionate. Means \pm SEM with different letters differ $(\mathrm{P}<0.05)$. 


\section{Discussion}

We have demonstrated previously that, while the amount of acetate or propionate we orally-gavaged into the rumen is physiologically relevant, representing approximately 10 percent of the ewe-lamb’s daily energy requirement, the hepatic portal vein concentration in the $4 \mathrm{~h}$ following the oral gavage was supraphysiological (Figure 1). In the ruminant, acetate is the major form of circulating energy in the fed state (De Jong, 1982). Acetate utilization is dependent on insulin (Baile and Mayer, 1967; Skarda and Bartos, 1969; Yang and Baldwin, 1973; Schwalm and Schultz, 1976). However, this experiment showed no increase in the secretion of insulin following an oral gavage of acetate. This is in agreement with other researchers who reported similar results in sheep (Manns and Boda, 1967; Trenkle, 1970), goats (De Jong, 1982), and cattle (McAtee and Trenkle, 1971). Similar to De Jong, (1982), in the current experiment, acetate did not appear to affect the secretion of glucagon.

In this experiment, an oral gavage of propionate increase plasma concentration of both insulin and glucagon in sheep. This is in agreement with De Jong, (1982) who reported similar findings in goats. It has been hypothesized that volatile fatty acids act directly on the alpha and beta cells of pancreatic islets of Langerhans. There is the possibility that glucagon is an intermediary between volatile fatty acids and insulin secretion because glucagon is a potent stimulator of insulin secretion (Bassett, 1971; Samols et al., 1972). In this study glucagon secretion increases coincident with insulin, which agrees with Bassett (1972), who reported similar results in sheep. However, it should be noted that glucagon is probably responsible for only a portion of the increase in 
insulin as insulin concentrations were reduced before glucagon returned to baseline concentrations.

From our previous work, we showed an increase in the concentration of propionate in the hepatic portal vein for approximately $4 \mathrm{~h}$ (Figure 2). It is surprising that the increased secretion of insulin and glucagon both returned to baseline before propionate leaving the rumen should have decreased. Therefore, we hypothesize that the initial increase in volatile fatty acids is a signal to secrete insulin and glucagon but ultimately concentrations of blood glucose would maintain the appropriate hormone secretion as seen in the monogastric (Grodsky, 1972). Rations that stimulate the production of propionate, increasing the portal-vein propionate concentration, may alter insulin and glucagon secretion. 


\section{Literature Cited}

Baile, C.A., and J. Mayer. 1967. Effects of insulin-induced hypoglycemia and hypoacetoemia on eating behavior in goats. J. Dairy Sci. 51:1495-1499.

Bassett, J.M. 1971. The effects of glucagon on plasma concentrations of insulin, growth hormone, glucose and free fatty acids in sheep: comparison with the effects of catecholamines. Aust. J. Biol. Sci. 24:311-320.

Bassett, J. M. 1972. Plasma glucagons concentrations in sheep: their regulation and relation to concentration of insulin and growth hormone. Austr. J. Biol. Sci. 25:12771287.

DeJong, A. 1982. Patterns of plasma concentrations of insulin and glucagon after intravascular and intraruminal administration of volatile fatty acids in the goat. $\mathrm{J}$. Endocrinol. 92:357.

Elliot, J. M. (1980). Propionate metabolism and vitamin B12. In Digestive physiology and metabolism in ruminants, pp. 485-503. Eds Y. ruckebusch \& P. Thivend. Lancaster: MTP Press Ltd.

Grodsky, G.M. 1972. A threshold distribution hypothesis for packet storage of insulin and its mathematical modeling. J. Clin. Invest. 51:2047-2059.

Harmon, D.L. 1992. Impact of nutrition on pancreatic exocrine and endocrine secretion in ruminants: A review. J. Anim. Sci. 70:1290-1301.

Horino, M., J. Machlin, F. Hertelendy, and D. M. Kipnis. 1968. Effect of shortChain fatty acids on plasma insulin in ruminants and nonruminant species.

Endocrinology 83:118.

Manns, J. G., and J. M. Boda. 1967. Insulin release by acetate, propionate, butyrate and glucose in lambs and adult sheep. Am. J. Physiol. 212:747.

McAtee, J.W., and A. Trenkle. 1971. Metabolic regulation of plasma insulin levels in cattle. J. Anim. Sci. 33:438-442.

Mineo, H., R Murao, S. Kato, and J. Ushijima. 1990. Effect of intravenous injection of short chain fatty acids on glucagons secretion in sheep. Jpn. J. Zootech. Sci. 61:349.

Manns, J. G., J.M. Boda, and R.F. Wiles. 1967. Probable role of propionate and butyrate in control of insulin secretion in sheep. Amer. J. Physiol. 212:756-764.

NRC. 1985. Pages 2-25 in Nutrient Requirements of Sheep, $6^{\text {th }}$ rev. ed. Natl. Acad. Press, Washington, DC. 
Samols, E., J.M. Tyler, and V. Marks. 1972. Glucagon-insulin interrelationships. In Glucagon Molecular Physiology: clinical and therapeutic implication. pp. 151-173. Eds P.J. Lefebvre and R.H. Unger. Oxford:Pergamon.

Schwalm, J.W., and L.H. Schultz. 1976. Blood and liver metabolites in fed and fasted diabetic goats. J. Dairy Sci. 59:262-269.

Skarda, J., and S. Bartos. 1969. The effect of insulin on the utilization of [U- $\left.{ }^{14} \mathrm{C}\right]$ glucose and [ $\left.\mathrm{I}^{14} \mathrm{C}\right]$ acetateby goat adipose tissue in vitro. J. of Endo. 44:115-119.

Stern, J. S., C. A. Baile, and J. Mayer. 1970. Are propionate and butyrate physiological regulators of plasma insulin in ruminants? Am. J. Physiol. 210:365.

Trenkle, A. 1970. Effects of short-chain fatty acids, feeding, fasting, and type of diet on plasma insulin levels in sheep. J. Nutr. 100:1323-1330.

Yang, Y.T., and R.L. Baldwin. 1973. Preparation and metabolism of isolated cells from bovine adipose tissue. J. Dairy Sci. 56:350-365. 


\section{ALTERATIONS IN THE RATE OF PROGESTERONE CLEARANCE INDUCED BY INSULIN, GLUCAGON, OR INSULIN TO GLUCAGON RATIO, IN A MOUSE HEPATIC CELL LINE}

\section{Abstract}

To determine the rate of progesterone clearance in response to challenge with different concentrations of insulin, glucagon or a combination of insulin and glucagon, a mouse hepatic line was plated in five 12 -well $\left(10^{5}\right.$ per well) plates with $5 \mathrm{ng} / \mathrm{ml}$ of progesterone added to the culture medium. To calculate the fractional rate of decay for progesterone, media were harvested $0,1,2,3$, and $4 \mathrm{hr}$ following treatment. The concentrations of progesterone in conditioned media were determined by radioimmunoassay. Cells also were cultured in the presence of insulin $(0,0.1,1.0$ and 10 $\mathrm{nM})$, glucagon $(0,0.01,0.1$, and $1.0 \mathrm{nM})$ or both insulin and glucagon at different ratios of insulin and glucagon ( 0 and $0,1.0$ and 1.0, 1.0 and 0.1 or 0.1 and 1.0, $\mathrm{nM}$ insulin and glucagon, respectively). In response to a challenge with insulin, there was a dose dependent decrease in progesterone disappearance. There was a reduction $(\mathrm{P}<0.05)$ in the rate of decay with the addition of $0.1 \mathrm{nM}$ insulin, when compared to control. Further, there was a greater reduction in the rate of decay in response to 1.0 and $10 \mathrm{nM}$ insulin (P $<0.05$ ) than control and $0.1 \mathrm{nM}$ insulin. There was no observable change in the disappearance of progesterone with either physiological $(0.01 \mathrm{nM})$ or pharmacological (0.1 and $1.0 \mathrm{nM}$ ) treatment of cells with glucagon. Pharmacological concentrations of glucagon $(1.0 \mathrm{nM})$ negated the effects of either 0.1 or $1.0 \mathrm{nM}$ insulin on the clearance of progesterone. However, with physiological concentrations of glucagon $(0.01 \mathrm{nM})$ and $1.0 \mathrm{nM}$ insulin, glucagon was not able to negate the reduction in progesterone 
disappearance caused by insulin. These data show that high concentrations of insulin reduce catabolism of progesterone in a mouse hepatic cell line.

KEYWORDS: Progesterone; Insulin; Glucagon; Hepatocyte; Mouse 


\section{Introduction}

The sheep embryo is particularly sensitive to reductions in peripheral concentrations of progesterone over a 48-h period on d 11 and 12 of pregnancy (Parr, 1992). It also has been shown that within the first three weeks of pregnancy concentrations of progesterone are elevated when ewes are fed a sub-maintenance diet (Cummings et al., 1971; Parr et al., 1982). When underfed, ovariectomized pregnant ewes were given exogenous progesterone, peripheral concentrations of progesterone were elevated compared to ewes not underfed (Parr et al., 1982). This indicates that the effects of nutrition may impact the metabolic clearance rate, rather than synthesis of progesterone by the corpus luteum (Parr et al., 1982).

Cytochrome P450 enzymes, particularly CYP3A4 and CYP2C19, contribute substantially to the hepatic catabolism of progesterone (Miller et al., 1963; Estergreen et al., 1977; Clemens and Estergreen, 1982; Rico, 1983; Guay, 1998; Bidstrup et al., 2003). Bidstrup et al. (2003) confirmed that the in vitro metabolism of progesterone was a NADPH-dependent process and that the activity of CYP3A4 (6 $\beta$ - hydroxysteroid dehydrogenase) and CYP2C19 (20ß-hydroxysteroid dehydrogenase) result in the formation of the major metabolites including $6 \beta$ hydroxyprogesterone and $20 \alpha-$ hydroxyprogesterone, respectively. Both CYP3A4 and CYP2C19 catabolize many different substrates and competition among these substrates for binding sites or limitations in enzyme cofactors may alter the ability of cytochrome P450 enzymes to metabolize a given substrate (Bidstrup et al., 2003).

Numerous researchers have shown that dietary restriction and negative energy balance reduce circulating concentrations of insulin (Mackey et al., 1999; Sinclair et al., 
2000). Further, Pell et al. (1983) have shown that concentrations of plasma insulin are lower in lactating versus non-lactating dairy cattle. To further emphasize lactational interactions, dairy cattle selected for milk yield show a lower circulating concentration of insulin (Armstrong et al., 2003). However, Selvaraju et al. (2002) found in cattle treated with insulin, circulating concentrations of progesterone were significantly increased. Therefore, reduced concentrations of insulin could reduce androgen and estradial production or clearance (Diskin et al., 2003).

The objectives of this experiment were to determine the rate of progesterone clearance in a murine hepatic cell line following challenge with insulin, glucagon or a combination of insulin and glucagon. 


\section{Materials and Methods}

A mouse hepatic cell line (cell line CRL-2390), was obtained from American Type Culture Collection, (Manassas, VA). The fetal bovine serum (Lot \# 1125143), penicillin-streptomyocin (10,000 units and 10,000 $\mu \mathrm{g} / \mathrm{ml}$, respectively; Lot \# 15140122), and Hank’s balanced salt solution (Lot 14170112) were obtained from Invitrogen (Carlsbad, CA). The medium (F-12K, Lot \# 3000357) was purchased from American Type Culture Collection (Manassas, VA). Insulin (Lot \# 064K8403), glucagon (Lot \# 123K8928), and progesterone (Lot \# 100K0204) were purchased from Sigma Chemical Co. (St. Louis, MO). All other reagents used were of the purest grade available.

Experiment

Cells $\left(10^{5}\right.$ per well) were plated in five 12 -well plates (wells $3.8 \mathrm{~cm}^{2}$, well volume $6 \mathrm{ml}$ ) in $1.0 \mathrm{ml}$ medium (F-12K) with $10 \%$ fetal bovine serum and 1\% penicillinstreptomyocin. The plates were incubated for $12 \mathrm{~h}$ at $36^{\circ} \mathrm{C}$ and $5 \% \mathrm{CO}_{2}$ to allow the cells to adhere to the wells and grow to $40 \%$ confluency.

Following the initial $12 \mathrm{~h}$ incubation period, the medium was aspirated out of the wells and $1.0 \mathrm{ml}$ of new medium with $10 \%$ fetal bovine serum and $1 \%$ penicillinstreptomyocin with the addition of $5 \mathrm{ng} / \mathrm{ml}$ of progesterone and one of 4 treatments $(0$, 0.1, 1.0 and $10 \mathrm{nM}$ insulin) was added to each well. Treatments were replicated in triplicate, and each plate contained all 4 treatments.

Five time points were used to calculate the fractional rate of decay for progesterone, $0,1,2,3$, and $4 \mathrm{hr}$. A preliminary experiment showed that from 0 to $4 \mathrm{hr}$ the cells continued to multiply, reaching confluency at approximately 4 hr (Figure 6). At 


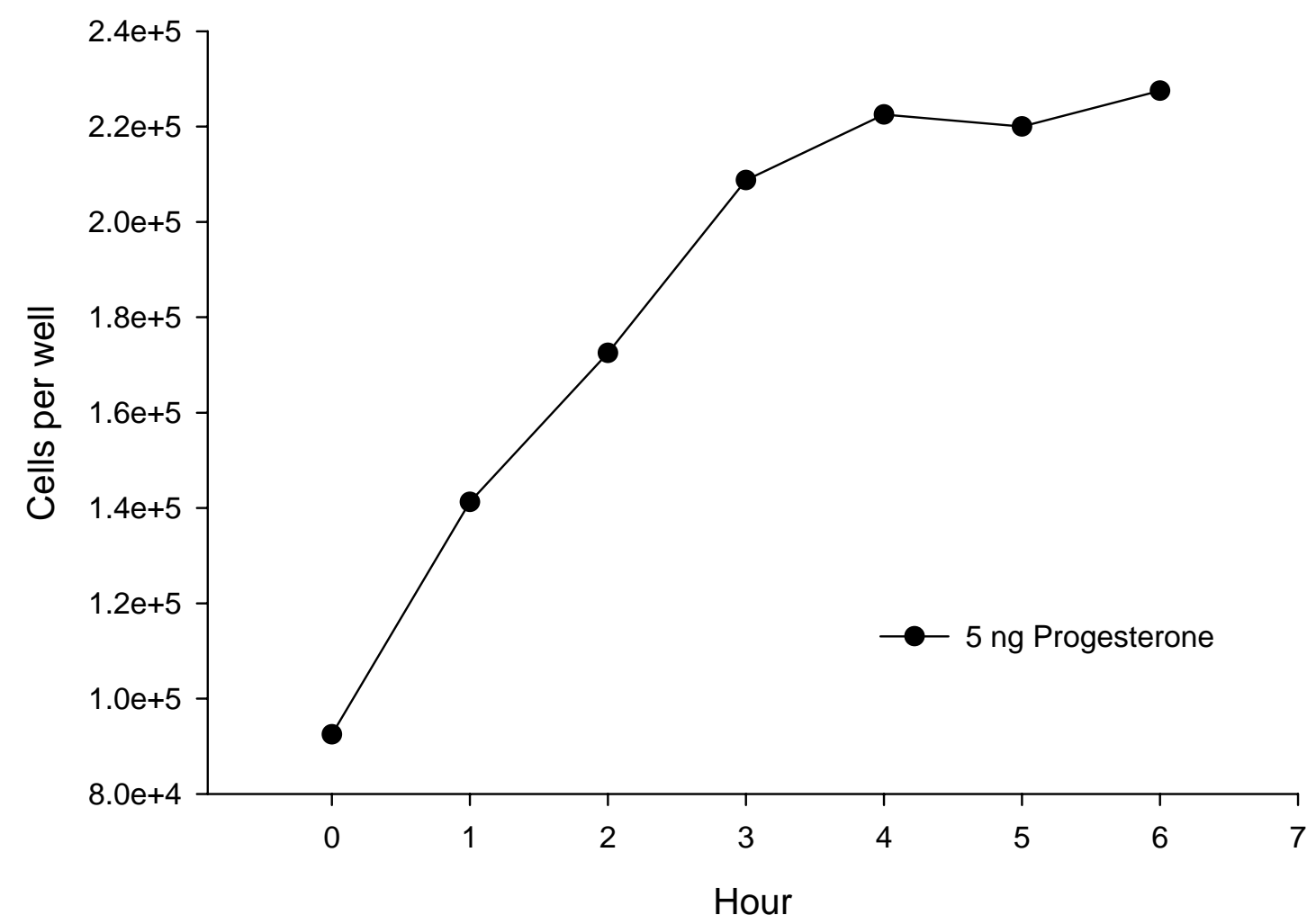

Figure 6: Number of hepatocytes per well during $6 \mathrm{~h}$ of culture in media containing 5 $\mathrm{ng} / \mathrm{ml}$ of progesterone. 
each time point, one plate was removed from the incubator and the medium was aspirated from each well into a microcentrifuge vial. For the $0 \mathrm{~h}, 1 \mathrm{ml}$ medium plus treatment was placed in each well and immediately aspirated back out of the well and placed into a microvial. The other four plates were placed back into the incubator at $36^{\circ} \mathrm{C}, 5 \% \mathrm{CO}_{2}$ and remained undisturbed until the appropriate hour. The vials were spun at $300 \mathrm{~g}$ and decanted into new vials, which were frozen until assayed for progesterone. The experiment was replicated 3 times. Concentrations of progesterone in conditioned media were determined by radioimmunoassay, with a sensitivity of $100 \mathrm{pg} / \mathrm{ml}$ and intra- and inter-assay CV of $6.5 \%$ and $7.6 \%$, respectively (Sheffel et al., 1982).

Cells were cultured in the presence of glucagon exactly as with insulin, except treatments included $0,0.01,0.1$, and $1.0 \mathrm{nM}$ of glucagon in place of insulin. Finally, cells were cultured in the presence of both insulin and glucagon as with insulin and glucagon alone, except the treatments contained different ratios of insulin and glucagon including 0 and $0,1.0$ and 1.0, 1.0 and 0.1 or 0.1 and 1.0, nM insulin and glucagon, respectively.

\section{Statistical Analysis}

Fractional rate coefficients were calculated for each treatment and then expressed as a percentage of the control coefficient. Statistical models included treatment effect (concentration of insulin or glucagon), time, replicate, and a treatment $\mathrm{x}$ time interaction in a complete block design. Preliminary analysis showed no significant differences among replicates of the experiment, so the data were combined and analyzed together. Concentrations of progesterone in media were analyzed using PROC GLM and means 
separation was performed using the DUNCANS procedure of SAS (SAS Inst., Inc., Cary, $\mathrm{NC})$.

\section{Results}

When cells were treated with insulin, there was a dose dependant decrease in the disappearance of progesterone (Figure 7). There was a reduction $(\mathrm{P}<0.05)$ in the rate of decay with the addition of $0.1 \mathrm{nM}$ insulin when compared to control (Figure 7). Further, there was a greater reduction in the rate of decay in response to 1.0 and $10 \mathrm{nM}$ insulin (P $<0.05)$ than with $0.1 \mathrm{nM}$ insulin. There was no observable change in the disappearance of progesterone with either physiological $(0.01 \mathrm{nM})$ or pharmacological $(0.1$ and $1.0 \mathrm{nM})$ treatment of cells with glucagon (Figure 8). Pharmacological concentrations of glucagon $(1.0 \mathrm{nM})$ negated (Figure 9) the effects of either 0.1 or $1.0 \mathrm{nM}$ insulin on the clearance of progesterone observed when cells were challenged with insulin alone (Figure 7).

However, with physiological concentrations of glucagon $(0.01 \mathrm{nM})$, glucagon was not able to negate the reduction in progesterone disappearance caused by $1.0 \mathrm{nM}$ insulin (Figure 9). 


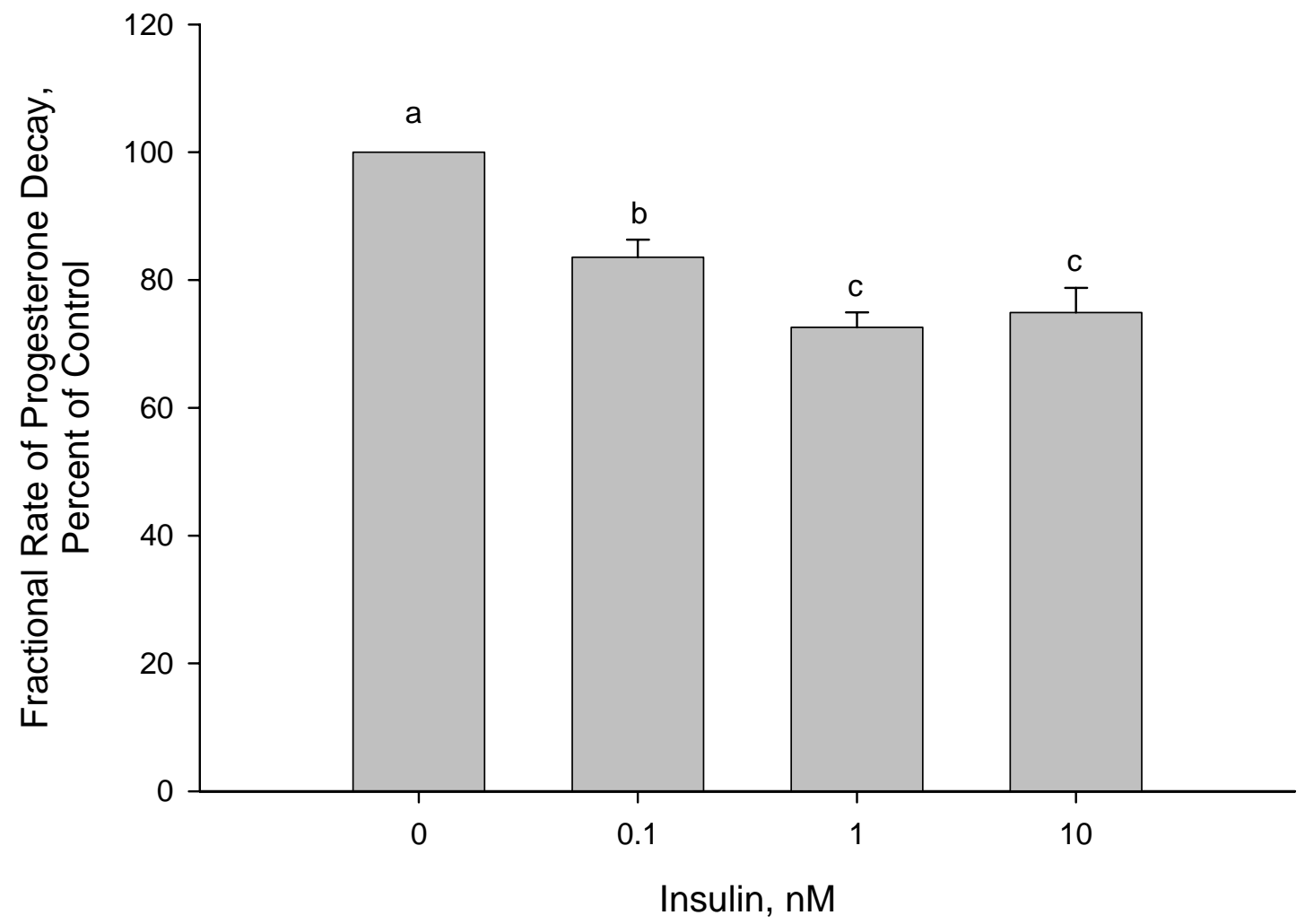

Figure 7: The fractional rate of decay of progesterone, by cells, challenged with $0,0.1,1$ and $10 \mathrm{nM}$ insulin. Means \pm SEM with different letters differ $(\mathrm{P}<0.05)$. 


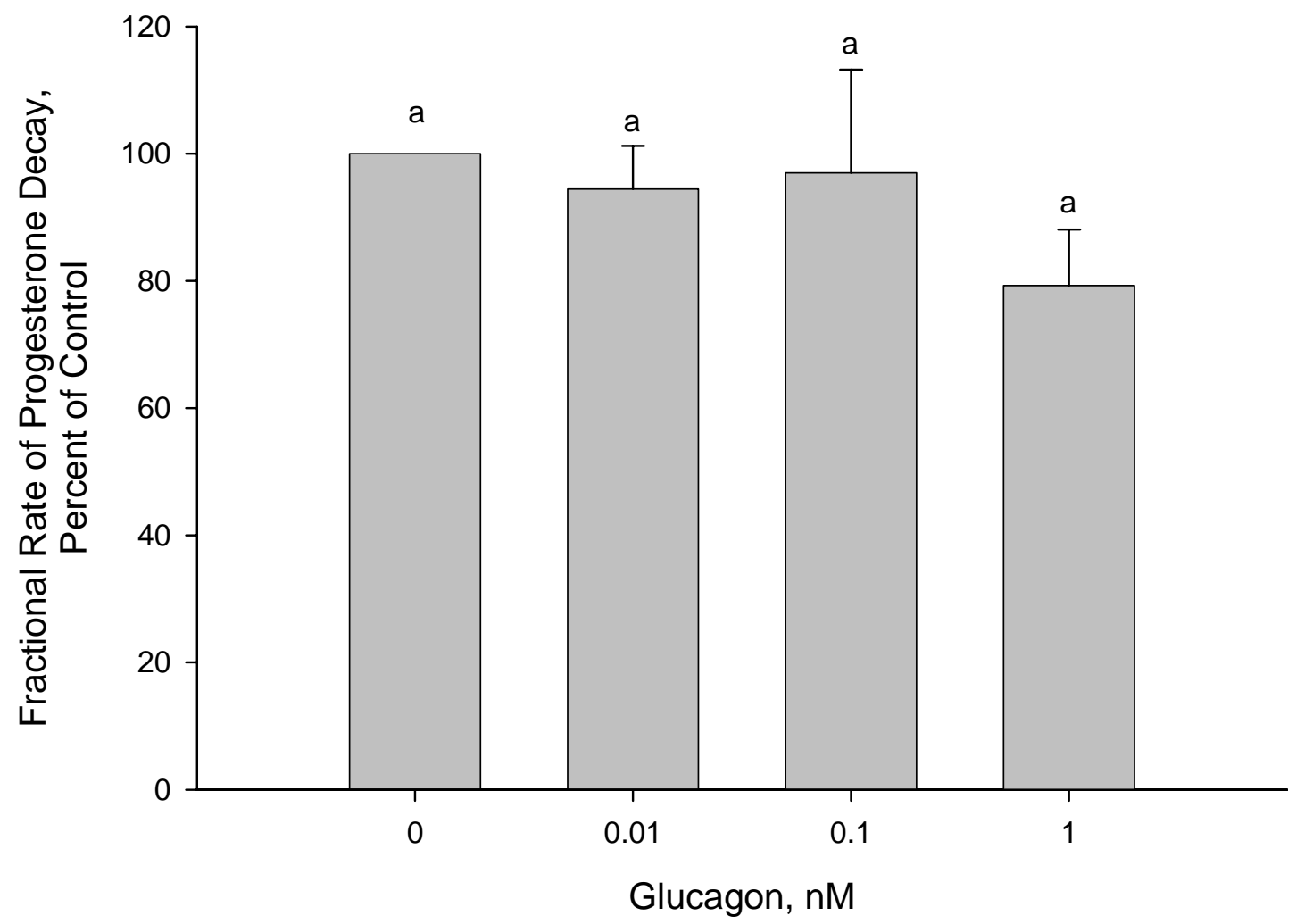

Figure 8: The fractional rate of decay of progesterone, by cells, challenged with $0,0.01$, 0.1 and $1.0 \mathrm{nM}$ glucagon. Means \pm SEM with different letters differ $(\mathrm{P}<0.05)$. 


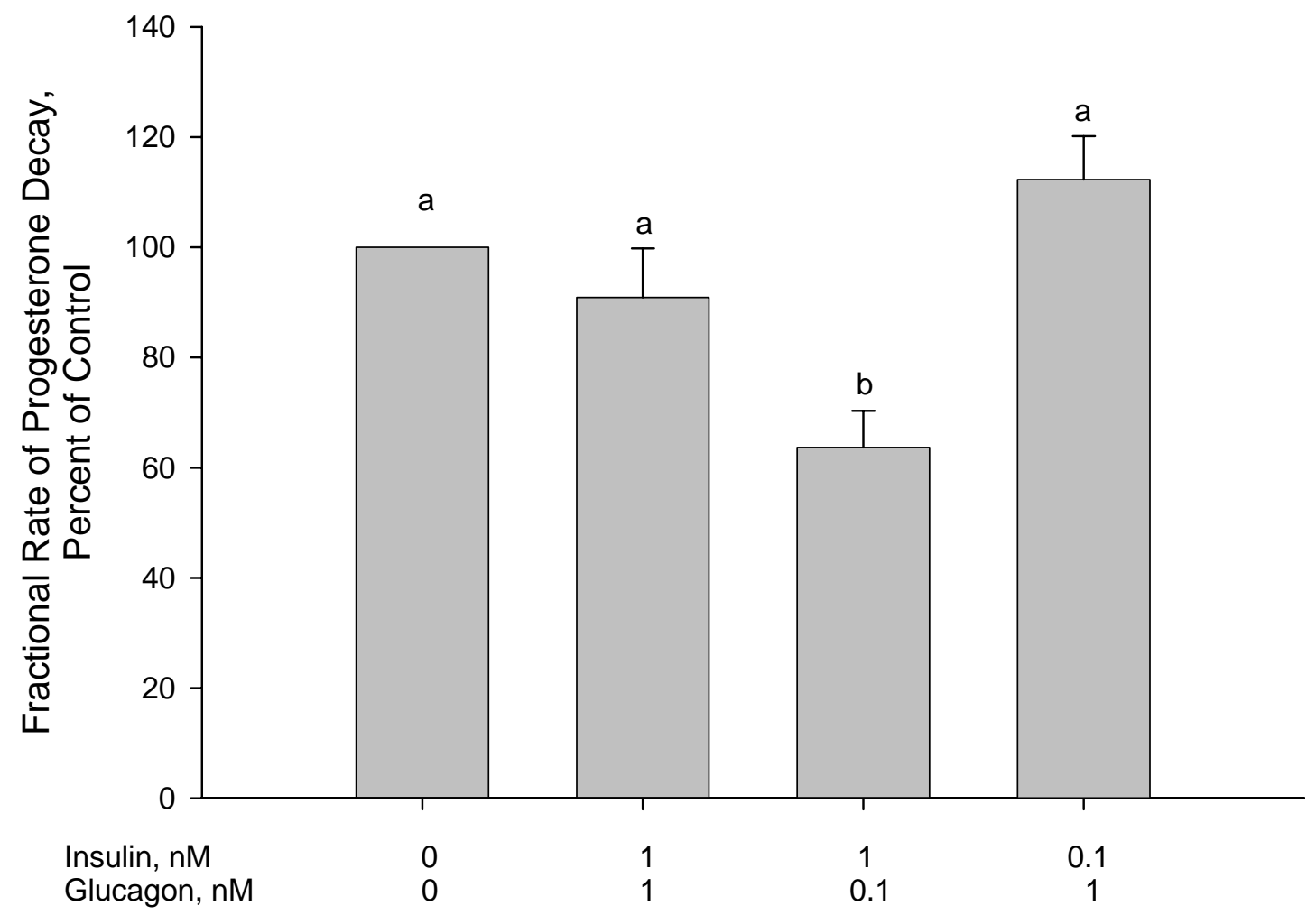

Figure 9: The fractional rate of decay of progesterone, by cells, challenged with different ratios of insulin and glucagon ( 0 and $0,1.0$ and 1.0, 1.0 and 0.1 or 0.1 and 1.0, $\mathrm{nM}$ insulin and glucagon, respectively). Means \pm SEM with different letters differ $(\mathrm{P}<$ $0.05)$. 


\section{Discussion}

The results from this experiment show that less progesterone is cleared by the hepatocyte when in the presence of insulin or insulin and physiological concentrations of glucagon. Further there was a dose response relationship between insulin treatment and progesterone clearance, with the exception that the highest dosage of insulin (10 nM) was not different than $1.0 \mathrm{nM}$. This was to be expected as the insulin receptor saturation in the mouse hepatocyte is approximately $1 \mathrm{nM}$, (Valverde et al., 1997), therefore the addition of $10 \mathrm{nM}$ insulin should not further decrease progesterone clearance beyond what was observed with $1.0 \mathrm{nM}$ insulin. Glucagon had no apparent effect on the clearance of progesterone, however, a pharmacological dosage was able to negate the effects of insulin.

In our earlier research (Figure 3), animals that were orally-gavaged with isoenergetic acetate or propionate, less progesterone was cleared with the propionate treatment. Further, an oral gavage of propionate significantly increased circulating concentrations of insulin (Figure 4). As seen in other research (De Jong, 1982), the oral gavage of propionate also increased the secretion of glucagon (Figure 5). However, it should be noted that the increased concentration of glucagon was similar to that in the physiological combination (1.0 insulin and 0.1 glucagon), which did not prevent insulin from decreasing the clearance of progesterone (Figure 9). Similarly, Selvaraju et al. (2002) found in cattle treated with insulin, circulating concentrations of progesterone were increased significantly. Diskin et al. (2003) concluded that reductions in the concentration of insulin could reduce androgen and estradial production or clearance. One could further extrapolate from this and earlier research with limited-fed versus over- 
fed ewes, that there would be differences in the insulin to glucagon ratio. Animals fed a glucagon-stimulating diet, which would be similar to the acetate gavage, had a reduced embryo survival, and reduced circulating concentrations of progesterone on $\mathrm{d} 4$ and 5 post-conception (Bassett et al., 1969). Further, when underfed, ovariectomized pregnant ewes were given exogenous progesterone peripheral concentrations of progesterone were elevated compared to ewes not underfed (Parr et al., 1982). This indicates that the effects of nutrition may impact the metabolic clearance rate, rather than synthesis of progesterone by the corpus luteum (Parr et al., 1982).

There are numerous experiments that demonstrate the effect of insulin on the messenger RNA and clearance of substrates by hepatocytes. Sidhu and Omiecinski (1999) cultured hepatocytes in either 0 or $1 \mathrm{nM}$ insulin. When exposed to phenobarbital the hepatocytes incubated in the absence of insulin showed a 1.5 to 2.0 fold increase in the messenger RNA for the cytochrome P450 enzymes. In addition, the time required to attain maximal gene expression was reduced in the non-insulin treated cultures (Sidhu and Omiecinski, 1999). Similarly, Sidhu et al. (2001) demonstrated again that suppression of messenger RNA for cytochrome P450 enzymes was reduced by insulin but was not the result of an alteration in phosphatidylinositol 3-kinase. Finally, there was an 80 to 90 percent reduction in the messenger RNA for hepatocyte derived cytochrome P450 enzymes when incubated in either 1.0 or $10 \mathrm{nM}$ insulin (Woodcroft and Novak, 1999). These researchers also incubated cells in a supra-physiological dose of $100 \mathrm{nM}$ of glucagon. There was an approximately 7-fold increase in messenger RNA for the cytochrome P450 enzymes. However, when $1 \mathrm{nM}$ insulin was added to the supraphysiological dose of glucagon, expression of the messenger RNA was similar to 
controls, indicating a mutual antagonistic signaling pathway in which insulin and glucagon negate each others effect on the expression of messenger RNA for the cytochrome P450 enzymes (Woodcroft and Novak, 1999).

The cytochrome P450 enzymes, particularly CYP3A4 and CYP2C19, which contribute substantially to the hepatic catabolism of progesterone, might be influenced by concentrations of insulin. Further, it should be noted that while messenger RNA expression for cytochrome P450 enzymes (CYP3A4 and CYP2C19) was not measured, other hepatic cytochrome P450 enzymes are altered by insulin. Our experiments demonstrate this same effect, however, further experiments elucidating the basis for the reduction in progesterone catabolism are warranted. 


\section{Literature Cited}

Armstrong, DG, J.G. Gong, and R. Webb. 2003. Interactions between nutrition and ovarian activity in cattle: physiological, cellular and molecular mechanisms. Reprod Suppl. 61:403-414.

Bassett, J.M., T.J. Oxborrow, I.D. Smith, and G.D. Thorburn. 1969. The concentration of progesterone in the peripheral plasma of the pregnant ewe. J. Endocrinol. 45:449-457.

Bidstrup, T.B., I. Bjornsdottir, U.G. Sidelmann, M.S. Thomsen, and K.T. Hansen. 2003. CYP2C8 and CYP3A4 are the principle enzymes involved in the human in vitro biotransformation of the insulin secretagogue repaglinide. Clin. Pharmacol. 56:305-314.

Clemens J.D. and V.L. Estergreen. 1982. Metabolism and conjugation of [4-14C] progesterone by bovine liver and adipose tissues, in vitro. Steroids 40:287-306.

Cumming, I.A., B.J. Mole, J. Obst, M.A. de B. Blockey, C.G. Winfield, and J.R. Goding. 1971. Increase in plasma progesterone caused by undernutrition during early pregnancy in the ewe. J. Reprod. Fert. 24:146-147.

De Jong, A. 1982. Patterns of plasma concentrations of insulin and glucagon after intravascular and intraruminal administration of volatile fatty acids in the goat. $\mathrm{J}$. Endocrinol. 92:357.

Diskin, M.G., D.R. Mackey, J.F. Roche, and J.M. Sreenan. 2003. Effects of nutrition and metabolic status on circulating hormones and ovarian follicle development in cattle. Anim Reprod Sci. 78:345-370.

Estergreen, V.L., Lin, M.T., Martin, E.L., Moss, G.E., Branen, A.L., Luedecke, L.O., and Shimoda, W. 1977. Distribution of progesterone and its metabolites in cattle tissues following administration of progesterone 4-C. J. Anim. Sci. 45:642-651.

Guay, D.R. 1998. Repaglinide, a novel, short-acting hypoglycemic agent for type 2 diabetes mellitus. Pharmacotherapy. 18:1195-1204.

Mackey, D.R., J.M. Sreenan, J.F. Roche, and M.G. Diskin. 1999. Effect of acute nutritional restriction on the incidence of anovulation and periovulatory estradiol and gonadotrophin concentrations in beef heifers. Biol. Reprod. 61:1601-1607.

Miller W.R., R. Williams, G.W. Pipes, and C.W. Turner. 1963. Conjugation, distribution and biological half-life ( $1 / 2$ ) of radioactive progesterone in plasma and red cells of bovine blood. J. Dairy Sci. 46:1402-1404.

Parr, R.A., I.A. Cumming, and I.J. Clarke. 1982. Effects of maternal nutrition and plasma progesterone concentrations on survival and growth of the sheep embryo in early gestation. J. Agric. Sci. 98:39-46. 
Parr, R.A., 1992. Nutrition-progesterone interactions during early pregnancy in sheep. Reprod. Fertil. Dev. 4:297-300.

Pell, J.M., R.A. Hill, C.E. Stewart, C.R. Weston, and H.C. Flick-Smith. 2000. Enhancement of insulin-like growth factor I activity by novel antisera: potential structure/function interactions. Endocrinology. 141:741-751.

Rico, A.G. 1983. Metabolism of endogenous and exogenous anabolic agents in cattle. J. Anim. Sci. 57:226-232.

Selvaraju, S., S.K. Agarwal, S.D. Karche, S.K. Srivastava, A.C. Majumdar, and U. Shanker. 2002. Fertility responses and hormonal profiles in repeat breeding cows treated with insulin. Anim. Reprod. Sci. 2322:1-9.

Sheffel, C.E., B.R. Pratt, W.L. Ferrell and E.K. Inskeep. 1982. Induced corpora lutea in the postpartum beef cow. II. Effects of treatment with progestogen and gonadotropins. J. Anim. Sci. 54:830-836.

Sidhu, J.S. and C.J. Omiecinski. 1999. Insulin-mediated modulation of cytochrome P450 gene induction profiles in primary rat hepatocyte cultures. J. Biochem. Toxicol. 13:1-9.

Sidhu, J.S., F. Liu, S.M. Boyle, and C.J. Omiecinski. 2001. PI3K inhibitors reverse the suppressive actions of insulin on CYP2E1 expression by activating stress-response pathways in primary rat hepatocytes. Mol. Pharmacol. 59:1138-1146.

Sinclair, K.D., M. Kuran, F.E. Gebbie, R. Webb, and T.G. McEvoy. 2000. Nitrogen metabolism and fertility in cattle. II. Development of oocytes recovered from heifers offered diets differing in their rate of nitrogen release in the rumen. J. Anim. Sci. 78:2670-2689.

Valverde, A.M., M. Lorenzo, T. Teruel, and M. Benito. 1997. Alterations in the Insulin Signaling Pathway Induced by Immortalization and H-ras Transformation of Brown Adipocytes. Endocrinology. 138:3195-3207.

Woodcroft, K.J., and R.F. Novak. 1999. The role of phosphatidylinositol 3-kinase, Src kinase, and protein kinase A signaling pathways in insulin and glucagon regulation of CYP2E1 expression. Biochem. Biophys. Res. Commun. 266:304-307. 


\section{GENERAL DISCUSSION}

It has been shown that circulating concentrations of progesterone are at least a critical indicator of possible embryo loss, or maybe more importantly may contribute directly to pregnancy retention. The overall purpose of these experiments was to study the catabolism of progesterone, because a greater understanding of progesterone catabolism may help to reduce late embryo or fetal loss, through the possible nutritional manipulation of progesterone catabolic rate.

Numerous researchers have suggested that alterations in dry matter intake are responsible for the differences seen in circulating concentrations of progesterone in animals fed at different levels relative to maintenance. In the first experiment, we utilized an isoenergetic, oral gavage of acetate or propionate such that a balanced diet with equal energy and dry matter intake was provided, but that the form of energy varied. Therefore, the alterations in the clearance of progesterone seen in experiment 1 were the result of the form of energy orally-gavaged and not variation in dry matter intake or energy balance.

These observations led us to experiment two, in which we utilized the exact same oral gavage of acetate or propionate to determine secretion patterns of both insulin and glucagon. Acetate did not increase the secretion of either insulin or glucagon. However, an oral gavage of propionate stimulated secretion of both insulin and glucagon in sheep.

It has been hypothesized that volatile fatty acids act directly on the alpha and beta cells of pancreatic islets of Langerhans. There is the possibility that glucagon is an intermediary between volatile fatty acids and insulin secretion because glucagon is a potent stimulator of insulin secretion. As we saw in experiment two, glucagon secretion increased 
coincident with insulin. However, glucagon was probably only responsible for a portion of the increase in insulin, as insulin concentrations were reduced before glucagon returned to baseline concentrations. In the first experiment, we observed that the increase in the concentration of propionate in the hepatic portal vein was for approximately 4 hours. In experiment two, we observed that the increased secretion of insulin and glucagon returned to baseline before propionate leaving the rumen should have decreased. Therefore, we hypothesized that the initial increase in volatile fatty acids is a signal to secrete insulin and glucagon but ultimately concentrations of blood glucose would maintain the appropriate hormone secretion.

In the last experiment, information from the first two experiments was to examine whether the propionate induced reductions in progesterone catabolism were mediated by insulin in cultured mouse hepatocytes. We were able to investigate whether hepatic catabolism of progesterone could be modulated in the absence of alterations in hepatic blood flow. The results from the experiment showed that less progesterone was cleared by the cells when in the presence of insulin and physiological concentrations of glucagon. Further there was a dose response relationship between insulin treatment and progesterone clearance, with the exception that the highest dosage of insulin $(10 \mathrm{nM})$ was not different than $1.0 \mathrm{nM}$. This was to be expected as the insulin receptor saturation in the mouse hepatocyte is approximately $1 \mathrm{nM}$. Glucagon had no apparent effect on the clearance of progesterone, however, a pharmacological dosage was able to negate the effects of insulin. Our hypothesis is that insulin causes a reduction in the expression of messenger RNA for the cytochrome P450 enzymes in the hepatocyte. 
Our experiments demonstrate that propionate stimulates insulin and in turn, insulin decreases the clearance of progesterone metabolized by the liver hepatocytes.

Further experiments elucidating the basis for the reduction in progesterone catabolism are warranted. 


\section{LITERATURE CITED}

Abecia, J.A., S.M. Rhind, T.A. Bramley, and S.R. McMillen. 1995. Steroid production and LH receptor concentrations of ovarian follicles and corpora lutea and associated rates of ova wastage in ewes given high and low levels of food intake before and after mating. Anim. Sci. 61:57-62.

Adams, N.R., J.A. Abordi, J.R. Briegel, and M.R. Sanders. 1994. Effect of diet on the clearance rate of estradiol-17 $\beta$ in the ewe. Biol. Reprod. 51:668-674.

Aiello, R.J., and L.E. Armentano. 1987. Effects of volatile fatty acids on propionate metabolism and gluconeogenesis in caprine hepatocytes. J. Dairy Sci. 70:2504-2510.

Aiello, R.J., L.E. Armentano, S.J. Bertics, and A.T. Murphy. 1989. Volatile fatty acid uptake and propionate metabolism in ruminant hepatocytes. J. Dairy. Sci. 72: 942-949.

Apgar, J., D. Aspros, J.E. Hixon, R.R. Saatman, and W. Hansel. 1975. Effect of restricted feed intake on the sensitivity of the bovine corpus luteum to LH in vitro. J. Anim. Sci. 41:1120-1123.

Armstrong, DG, T.G. McEvoy, G. Baxter, J.J. Robinson, C.O. Hogg, K.J. Woad, R. Webb and K.D. Sinclair. 2001. Effect of dietary energy and protein on bovine follicle dynamics and embryo production in vitro: associations with the ovarian insulin-like growth factor system. Biol. Reprod. 64:1624-1632.

Armstrong, DG, J.G. Gong, and R. Webb. 2003. Interactions between nutrition and ovarian activity in cattle: physiological, cellular and molecular mechanisms. Reprod Suppl. 61:403-414.

Assanasen, C., C. Mineo, D. Seetharam, I.S. Yuhanna, Y.L. Marcel, M.A. Connelly, D.L. Williams, M. de la Llera-Moya, P.W. Shaul, and D.L. Silver. 2005. Cholesterol binding, efflux, and a PDZ-interacting domain of scavenger receptor-BI mediate HDL-initiated signaling. J. Clin. Invest. 115:969-977.

Attardi, B., and H.K. Happe. 1986. Modulation of the estradiol-induced luteinizing hormone surge by progesterone or antiestrogens: effects on pituitary gonadotropinreleasing hormone receptors. Endocrinology. 119:274-283.

Attardi, B, B. Klatt, G.E. Hoffman, and M.S. Smith. 1997. Facilitation or inhibition of the estradiol-induced gonadotropin surge in the immature rat by progesterone: regulation of GnRH and LH messenger RNAs and activation of GnRH neurons. J Neuroendocrinol. 9:589-599.

Ayalon, N. 1978. A review of embryonic mortality in cattle. J. Reprod. Fertil. 54:483493. 
Baile, C.A., and J. Mayer. 1967. Effects of insulin-induced hypoglycemia and hypoacetoemia on eating behavior in goats. J. Dairy Sci. 51:1495-1499.

Bamberg, E., and F. Schwarzenberger. 1990. Fecal steroid assay for monitoring of estrous cycle and pregnancy. In: Kaneko JJ (ed), Proc IVth Cong. Int. Soc. Anim. Clin. Biochem. Davis: Univ California, p 95-99.

Bartol, F.F., R.M. Roberts, F.W. Bazer, G.S. Lewis, J.D. Godkin, and W.W. Thatcher. 1985. Characterization of proteins produced in vitro by periattachment bovine conceptuses. Biol Reprod. 32:681-693.

Bassett, J.M., T.J. Oxborrow, I.D. Smith, and G.D. Thorburn. 1969. The concentration of progesterone in the peripheral plasma of the pregnant ewe. J. Endocrinol. 45:449-457.

Bassett, J.M. 1971. The effects of glucagon on plasma concentrations of insulin, growth hormone, glucose and free fatty acids in sheep: comparison with the effects of catecholamines. Aust. J. Biol. Sci. 24:311-320.

Bassett, J. M. 1972. Plasma glucagons concentrations in sheep: their regulation and relation to concentration of insulin and growth hormone. Austr. J. Biol. Sci. 25:12771287.

Beal, W.E., R.E. Short, R.B. Staigmiller, R.A. Bellows, C.C. Kaltenbach, and T.G. Dunn. 1978. Influence of dietary energy intake on bovine pituitary and luteal function. J. Anim. Sci. 46:181-188.

Bensadoun, A., and J.T. Reid. 1962. Estimation of rate of portal blood flow in ruminants: effect of feeding, fasting, and anesthesia. J. Dairy. Sci. 45:540-543.

Bergman, E.N., and J.E. Wolff. 1971. Metabolism of volatile fatty acids by liver and portal-drained viscera in sheep. Am. J. Physiol. 221:586-592.

Berman, E.N. 1975. Production and utilization of metabolites by the alimentary tract as measured in portal and hepatic blood. In Digestion and Metabolism in the Ruminant. Eds. I.W. McDonald and A.C.I. Warmer. Armidale, Aust. pp. 293-305.

Bergman, E.N. 1990. Energy contributions of volatile fatty acids from the gastrointestinal tract in various species. Phys. Rev. 70:567-590.

Bidstrup, T.B., I. Bjornsdottir, U.G. Sidelmann, M.S. Thomsen, and K.T. Hansen. 2003. CYP2C8 and CYP3A4 are the principle enzymes involved in the human in vitro biotransformation of the insulin secretagogue repaglinide. Clin. Pharmacol. 56:305-314.

Bindon, B.M. 1971. Role of progesterone in implantation in the sheep. J. Reprod. Fert. 24:146. 
Bolet, G. 1986. Timing and extent of embryonic mortality in pigs, sheep, and goats: Geneitic variability: In: Embryonic Mortality in Farm Animals. Eds. J.M. Sreenan, and M.G. Diskin. Dordrech, Boston, MA.

Boone, W.R., J.R. Hill Jr., S.W. Kennedy, and D.M. Henricks. 1975. The influence of nutrition on reproduction in the ewe with special emphasis on progesterone concentration. Theriogenology. 3:140-151.

Bottari SP, A. Vokaer, E. Kaivez, J.P. Lescrainier, and G.P. Vauquelin. 1983. Differential regulation of alpha-adrenergic receptor subclasses by gonadal steroids in human myometrium. J Clin Endocrinol Metab. 57:937-941.

Brann, D.W., J.L. O'Conner, M.F. Wade, P.L. Zamorano, and V.B. Mahesh. 1993. Regulation of anterior pituitary gonadotropin subunit mRNA levels during the preovulatory gonadotropin surge: a physiological role of progesterone in regulating LHbeta and FSH-beta mRNA levels. J Steroid Biochem Mol Biol. 46:427-437.

Brenner, R.M., J.A. Resko, and N.B. West. 1974. Cyclic changes in oviductal morphology and residual cytoplasmic estradiol binding capacity induced by sequential estradiol--progesterone treatment of spayed Rhesus monkeys. Endocrinology. 95:10941104.

Bridges, P.J., D.J. Wright, W.I. Buford, N. Ahmad, H. Hernandez-Fonseca, M.L. McCormick, F.N. Schrick, R.A. Dailey, P.E. Lewis, and E.K. Inskeep. 2000. Ability of induced corpora lutea to maintain pregnancy in beef cows. J. Anim. Sci. 78:2942-2949.

Brown, J.L., S.K. Wasser, D.E. Wildt, and L.H. Graham. 1994. Comparitive aspects of steroid hormone metabolism and ovarian activity in felids, measured noninvasively in feces. Biol. Reprod. 51:776-786.

Brown, M.S., and J.L. Goldstein. 1986. A receptor-mediated pathway for cholesterol homeostasis. Science. 232:34-47.

Buchanan, K. D., J. E. Vance, and R. H. Williams. 1969. Insulin and glucagon release from isolated islets of Langerhans: effect of enteric factors. Diabetes. 18:381.

Bulman, D. C. and Lamming, G. E. 1979. The use of milk progesterone analysis in the study of oestrus detection, herd fertility and embryonic mortality in dairy cattle. Br. Vet. J. 135:559-567.

Burrin, D.G., C.L. Ferrell, J.H. Eisemann, R.A. Britton, and J.A. Nienaber. 1989. Effect of level of nutrition on splanchnic blood flow and oxygen consumption in sheep. Br. J. Nutr. 62:23-34.

Butler, W.R. 2000. Nutritional interactions with reproductive performance in dairy cattle. Anim. Reprod. Sci. 60-61:449-457. 
Caffrey, J.L., P.W. Fletcher, M.A. Diekman, P.L. O'Callaghan, and G.D. Niswender. 1979. The activity of ovine luteal cholesterol esterase during several experimental conditions. Biol Reprod. 21:601-608.

Cartmill, J. A., El-Zarkouny, S. Z., Hensley, B. A., Lamb, G. C., and Stevenson, J. S. 2000. Stage of cycle, incidence and timing of ovulation, and pregnancy rates in dairy cattle after three timed breeding protocols. J. Anim. Sci. 78:216 (Abst.)

Casida, L.E. and E.J. Warwick. 1945. The necessity of the corpus luteum for maintenance of pregnancy in the ewe. J. Anim. Sci. 4:34-36.

Chesney, T.M., and J.G. Schofield. 1969. Studies on the secretion of pancreatic glucagon. Diabetes. 18:627.

Chesworth, J.M., and M.P. Easdon. 1983. Effect of diet and season on steroid hormones in the ruminant. Steroid Biochem. 19:715-723.

Clemens J.D. and V.L. Estergreen. 1982. Metabolism and conjugation of [4-14C] progesterone by bovine liver and adipose tissues, in vitro. Steroids 40:287-306.

Crivello, J.F. and C.R. Jefcoate, 1978. Mechanisms of corticotropin action in rat adrenal cells. I. The effects of inhibitors of protein synthesis and of microfilament formation on corticosterone synthesis. Biochim Biophys Acta. 542:315-329.

Cumming, I.A., B.J. Mole, J. Obst, M.A. de B. Blockey, C.G. Winfield, and J.R. Goding. 1971. Increase in plasma progesterone caused by undernutrition during early pregnancy in the ewe. J. Reprod. Fert. 24:146-147.

Curry, D. L. 1970. Glucagon potentiation of insulin secretion by the perfused rat pancreas. Diabetes. 19:420.

De Jong, A. 1982. Patterns of plasma concentrations of insulin and glucagon after intravascular and intraruminal administration of volatile fatty acids in the goat. $\mathrm{J}$. Endocrinol. 92:357.

Desaulniers, D.M., A.K. Goff, K.J. Betteridge, J.E. Rowell, and P.F. Flood. 1989. Reproductive hormone concentrations in feces during the estrous cycle and pregnancy in

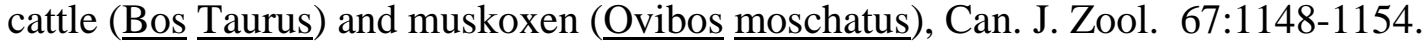

Digregorio, G.B. and T.M. Nett. 1995. Estradiol and progesterone influence the synthesis of gonadotropins in the absence of gonadotropin-releasing hormone in the ewe. Biol Reprod. 53:166-172.

Diskin, M. G. and Sreenan, J. M. 1980. Fertilization and embryonic mortality rates in beef heifers after artificial insemination. J. Reprod. Fertil. 59:463-468. 
Diskin, M.G., D.R. Mackey, J.F. Roche, and J.M. Sreenan. 2003. Effects of nutrition and metabolic status on circulating hormones and ovarian follicle development in cattle. Anim Reprod Sci. 78:345-370.

Dixon, A.B. 2004. Late embryonic and fetal mortality in the ewe. Ph.D. Dissertation. West Virginia University, Morgantown.

Dobson, A., and A.T. Phillipson. 1956. The influence of the contents of the rumen and of adrenaline upon its blood supply. J. Physiol. 133:76-77.

Donaldson, L.E., J.N. Bassett, and G.D. Thorburn. 1970. Peripheral plasma progesterone concentration of cows during puberty, oestrous cycle, pregnancy and lactation and the effects of undernutrition on exogenous oxytocin and progesterone concentration. J. Endocrinol. 48:599-614.

Dunn, T.G., J. Rone, C.C. Kaltenbach, L.A. Van der Walt, M.L. Riley, and A.M. Akbar. 1974. Hormone changes during underfeeding in beef cows. J. Anim. Sci. 39:206 (Abst.).

Dunne, L. D., Diskin, M. G., and Sreenan, J. M. 2000. Embryo and foetal loss in beef heifers between day 14 of gestation and full term. Anim. Reprod. Sci. 58:39-44.

Easdon, M.P., and J.M. Chesworth. 1980. Effect of undernutrition on the levels of some hormones in the blood of beef heifers. Proc. $9^{\text {th }}$ Int. Cong. Anim. Reprod. And AI. Madrid. Vol. III 354.

Elliot, J. M. (1980). Propionate metabolism and vitamin B12. In Digestive physiology and metabolism in ruminants, pp. 485-503. Eds Y. ruckebusch \& P. Thivend. Lancaster: MTP Press Ltd.

El-Zarkouny, S. Z., Cartmill, J. A., Hensley, B. A., and Stevenson, J. S. 2000.

Progesterone increases pregnancy rates and embryo survival in lactating dairy cows. J. Dairy Sci. 83:217 (Abst.).

Estergreen, V.L., Jr., O.L. Frost, W.R. Gomes, R.E. Erb, and J.F. Bullard. 1967. Effect of ovariectomy on pregnancy maintenance and parturition in dairy cows. J. Dairy Sci. 50:1293-1295.

Estergreen, V.L., Lin, M.T., Martin, E.L., Moss, G.E., Branen, A.L., Luedecke, L.O., and Shimoda, W. 1977. Distribution of progesterone and its metabolites in cattle tissues following administration of progesterone 4-C. J. Anim. Sci. 45:642-651.

Evans, R.W. and W.W. Leavitt. 1980. Progesterone inhibition of uterine nuclear estrogen receptor: dependence on RNA and protein synthesis. Proc Natl Acad Sci USA. 77:5856-5860. 
Faulkner, A., and H.T. Pollock. 1991. Effect of lactation on gluconeogenesis and ketogenesis in ovine hepatocytes. Comp. Biochem. Physiol. B. 98:283-286.

Ferrell, C.L., R.A. Britton, and H.C. Freetly. 1992. Chronic catheterization of portal and hepatic veins in sheep. In: P.J. Dziuk and M.B. Wheeler (Ed.) Handbook of Methods for Study of Reproductive Physiology of Domestic Animals. Dept. of Animal Science, Univ. of Illinois, Urbana.

Folman, Y., M. Rosenberg, Z. Herz, and M. Davidson. 1973. The relationship between plasma progesterone concentration and conception in postpartum dairy cows maintained on two levels of nutrition. J. Reprod. Fert. 34:267-278.

Freetly, H.C. and C.L. Ferrell. 1999. Relationship of portal-drained viscera and liver net flux of glucose, lactate, volatile fatty acids, and nitrogen metabolites to milk production in the ewe. J. Dairy Sci. 82:597-604.

Garrett, J. E., R.D. Geisert, M.T. Zavy, and G. L. Morgan. 1988. Evidence for maternal regulation of early conceptus growth and development in beef cattle. J. Reprod. Fertil. 84:437-446.

Glister, C., D.S. Tannetta, N.P. Groome, and P. Knight. 2001. Interactions between follicle stimulating hormone and growth factors in modulating secretion of steroids and inhibin-related peptides by non-luteinized bovine granulosa cells. Biol. Reprod. 65:1020-1028.

Gombe, S., and W. Hansel. 1973. Plasma luteinizing hormone (LH) and progesterone levels in heifers on restricted energy intakes. J. Anim. Sci. 37:728-733.

Gong, JG, W.J. Lee, P.C. Garnsworthy, and R. Webb. 2002a. Effect of dietary-induced increases in circulating insulin concentrations during the early postpartum period on reproductive function in dairy cows. Reproduction. 123:419-427.

Gong, JG, D.G. Armstrong, G. Baxter, C.O. Hogg, P.C. Garnsworthy, and R. Webb. 2002b. The effect of increased dietary intake on superovulatory response to FSH in heifers. Theriogenology. 57:1591-1602.

Grodsky, G.M. 1972. A threshold distribution hypothesis for packet storage of insulin and its mathematical modeling. J. Clin. Invest. 51:2047-2059.

Grummer, R.R., and D.J. Carroll. 1988. A review of lipoprotein cholesterol metabolism: importance to ovarian function. J Anim Sci. 66:3160-3173.

Guay, D.R. 1998. Repaglinide, a novel, short-acting hypoglycemic agent for type 2 diabetes mellitus. Pharmacotherapy. 18:1195-1204. 
Gutierrez, G.C., B.K. Campbell, and R. Webb. 1997. Development of a long-term bovine granulosa cell culture system: induction and maintenance of oestradiol production, response to follicle stimulating hormone and morphological characteristics. Biol. Reprod. 56:608-616.

Gutniak, M., C. Orskov, J.J. Holst, B. Ahrén, and S. Efendic. 1992 Antidiabetogenic effect of glucagon-like peptide-1 (7-36) amide in normal subjects and patients with diabetes mellitus. N. Engl. J. Med. 326:1316-1322.

Hammond, J. 1927. The physiology of reproduction in the cow. University Press, Cambridge, England.

Hanukoglu, I. 1992. Steroidogenic enzymes: structure, function, and role in regulation of steroid hormone biosynthesis. J. Steroid Biochem. 43:779-804.

Harmon, D.L. 1992. Impact of nutrition on pancreatic exocrine and endocrine secretion in ruminants: A review. J. Anim. Sci. 70:1290-1301.

Harrison, L.M. and R.D. Randel. 1986. Influence of insulin and energy intake on ovulation rate, luteinizing hormone and progesterone in beef heifers. J Anim Sci. 63:1228-1235.

Heitmann, R.N., S.C. Sensenig, C.K. Reynolds, J.M. Fernandez, and D.J. Dawes. 1986. Changes in energy metabolite and regulatory hormone concentrations and net fluxes across splanchnic and peripheral tissues in fed and progressively fasted ewes. J. Nutr. 116: 2516-2524.

Hess, E. 1920. Die sterilitat des rindes. (Sterility in cattle). M. \& H. Schaper Verlag, Hannover, Germany.

Hill, J.R. Jr., D.R. Lammond, D.M. Henricks, J.F. Dickey, and G.D. Niswender. 1970. The effect of undernutrition on ovarian function and fertility in beef heifers. Biol. Reprod. 2:78-84.

Holness, D.H., J.D.H. Hopley, and D.H. Hale. 1979. Ovarian activity and conception during the post-partum period in beef cows. Anim. Prod. 28:446 (Abst.).

Horino, M., J. Machlin, F. Hertelendy, and D. M. Kipnis. 1968. Effect of shortChain fatty acids on plasma insulin in ruminants and nonruminant species.

Endocrinology 83:118.

Hulet, C.V., H.P. Voightlander, A.L. Pope, and L.E. Casida. 1956. The nature of earlyseason infertility in sheep. J. Anim. Sci. 15:607-616. 
Hwang, J., and K.M. Menon. 1983. Characterization of low density and high density lipoprotein receptors in the rat corpus luteum and regulation by gonadotropin. J. Biol. Chem. 258:8020-8027.

Ing, N.H. and M.B. Tornesi. 1997. Estradiol upregulates estrogen receptor and progesterone receptor gene expression in specific ovine uterine cells. Biol. Reprod. 56:1205-1215.

Ing, N.H. 2005. Steroid hormones regulate gene expression posttranscriptionally by altering the stabilities of messenger RNAs. Biol. Reprod. 72:1290-1296.

Inskeep, E. K. 2002. Factors that affect embryonic survival in the cow: Application of technology to improve calf crop. In Factors Affecting Calf Crop: Biotechnology of Reproduction. Edited by Michael J. Fields, Robert S. Sand, and Joel Y. Yelich. CRC Press, Boca Raton FL. Chapter 19. p 255-275.

Iversen, J. 1970. Secretion of immunoreactive insulin and glucagon from the isolated perfused canine pancreas following cyclic AMP, glucagon and theophylline. Proceedings of the $7^{\text {th }}$ Congress of the International Diabetes Federation. Excerpta Medica Foundation.

Iversen, J. 1971. Secretion of glucagon from the isolated, perfused canine pancreas. J. Clin. Invest. 50:2123-2136.

Iwai M, H. Kanzaki, M. Fujimoto, K. Kojima, H. Hatayama, T. Inoue, T. Higuchi, H. Nakayama, T. Mori, and J. Fujita. 1995. Regulation of sex steroid receptor gene expression by progesterone and testosterone in cultured human endometrial stromal cells. J. Clin. Endocrinol. Metab. 80:450-454.

Janovick, J.A. and P.M. Conn. 1996. Progesterone diminishes the sensitivity of gonadotropin-releasing hormone-stimulated luteinizing hormone (LH) release and protects an LH pool from desensitization: actions opposed by cholera toxin.

Endocrinology. 137:1823-1827.

Johnson, K.R., R.H. Ross, and D.L. Fourt. 1958. Effect of progesterone administration on reproductive efficiency. J. Anim. Sci. 17:386-390.

Johnson, K.R. and R.E. Erb. 1962. Maintenance of pregnancy in ovariectomized cattle with progestin compounds and their effect on progestin levels in the corpus luteum. J. Dairy Sci. 45:633-639.

Johnson, W.J., M.C. Phillips, and G.H. Rothblat. 1997. Lipoproteins and cellular cholesterol homeostasis. Subcell. Biochem. 28:235-276. 
Kaneko, K.J., C. Gelinas, and J. Gorski. 1993. Activation of the silent progesterone receptor gene by ectopic expression of estrogen receptors in a rat fibroblast cell line. Biochemistry. 32:8348-8359.

Kasa-Vubu, J.Z., G.E. Dahl, N.P. Evans, L.A. Thrun, S.M. Moenter, V. Padmanabhan, and F.J. Karsch. 1992. Progesterone blocks the estradiol-induced gonadotropin discharge in the ewe by inhibiting the surge of gonadotropin-releasing hormone. Endocrinology. 131:208-212.

Kastelic J. P. 1994. Noninfectious embryonic loss in cattle. Vet. Med. 584-589.

Katz, M.L., and E.N. Bergman. 1969. Simultaneous measurements of hepatic and portal venous blood flow in the sheep and dog. Am. J. Physiol. 216:946-952.

Kemmler, W., and D. S. Steiner. 1970. Conversion of proinsulin to insulin in a subcellular fraction from rat islets. Biochem. Biophys. Res. Commun. 41:1223.

Kerr, B.M., K.E. Thummel, and C.J. Wurden, et al. 1994. Human liver carbamazepine metabolism- role of CYP3A4 and CYP2C8 in 10, 11-epoxide formation. Biochem. Pharmacol. 47:1969-1979.

Ketterer, H., A. M. Eisentraut, and R. H. Unger. 1967. Effect upon insulin secretion of physiologic doses of glucagons administered via the portal vein. Diabetes. 16:283.

King, W. A. 1991. Embryo-mediated pregnancy failure in cattle. Can. Vet. J. 32:99103.

Kirkpatrick, J.F., D.F. Gudermuth, R.L. Flagan, J.C. McCarthy, and B.L. Lasley. 1993. Remote monitoring of ovulation and pregnancy of Yellowstone bison. J. Wildl. Manag. 57:407-412.

Klinger, C. 1991. Zyklusdiagnose beim Rind mittels Gestagenbestimmung im Kot. Thesis, Vet Med University, Vienna.

Kraus, W.L. and B.S. Katzenellenbogen. 1993. Regulation of progesterone receptor gene expression and growth in the rat uterus: modulation of estrogen actions by progesterone and sex steroid hormone antagonists. Endocrinology. 132:2371-2379.

Krisans, S.K. 1996. Cell compartmentalization of cholesterol biosynthesis. Ann N Y Acad Sci. 804:142-164.

Kristensen, N.B., S.G. Pierzynowski, and A. Danfaer. 2000. Net portal appearance of volatile fatty acids in sheep intraruminally infused with mixtures of acetate, propionate, isobutyrate, and valerate. J. Anim. Sci. 78:1372-1379. 
Kummerfield, H. L., Oltenacu, A. B., and Foote, R. H. 1978. Embryonic mortality in dairy cows estimated by nonreturns to service, estrus, and cyclic milk progesterone patterns. J. Dairy Sci. 61:1773-1777.

Kunkel, R.N., W.C. Hagele, and A.C. Mills. 1977. Effect of recipient progesterone supplementation of morula and blastocyst survival. J. Amin. Sci. 45:181 (Abst.)

Lamond, D.R., R.G. Gaddy, and S.W. Kennedy. 1972. Influence of season and nutrition of luteal plasma progesterone in Rambouillet ewes. J. Anim. Sci. 34:626-629.

Lang, D. A., D. R. Matthews, J. Peta, and R. C. Turner. 1979. Cyclic oscillations of basal plasma glucose and insulin concentrations in human beings. N. Engl. J. Med. 301:1023-1027.

Larter, N.C., R. Rajamahendran, and K. Sivakumaran. 1994. Immunoreactive fecal progestins as indicators of reproductive status. Vet. Rec. 134:474-475.

Lestavel, S., and J.C. Fruchart. 1994. Lipoprotein receptors. Cell Mol Biol. 40:461-481.

Lomax, M.A., and G.D. Baird. 1983. Blood flow and nutrient exchange across the liver and gut of the dairy cow. Effect of lactation and fasting. Br. J. Nutr. 49:481-496.

Looney, M.C. R.L. Baldwin, and C.C. Calvert. 1987. Gluconeogenesis in isolated lamb hepatocytes. J. Anim. Sci. 64:283-294.

Lozano, J.M., J.A. Abecia, F. Forcada, L. Zarazaga, and B. Alfaro. 1998. Effect of undernutrition on the distribution of progesterone in the uterus of ewes during the luteal phase of the estrous cycle. Theriogenology. 49:539-546.

Mackey, D.R., J.M. Sreenan, J.F. Roche, and M.G. Diskin. 1999. Effect of acute nutritional restriction on the incidence of anovulation and periovulatory estradiol and gonadotrophin concentrations in beef heifers. Biol. Reprod. 61:1601-1607.

Manns, J. G., and J. M. Boda. 1967. Insulin release by acetate, propionate, butyrate and glucose in lambs and adult sheep. Am. J. Physiol. 212:747.

Manns, J. G., J.M. Boda, and R.F. Wiles. 1967. Probable role of propionate and butyrate in control of insulin secretion in sheep. Amer. J. Physiol. 212:756-764.

Maurer, R. R. and Chenault, J. R. 1983. Fertilization failure and embryonic mortality in parous and nonparous beef cattle. J. Anim. Sci. 56:1186-1189.

McAtee, J.W., and A. Trenkle. 1971. Metabolic regulation of plasma insulin levels in cattle. J. Anim. Sci. 33:438-442. 
McDonald, L.E., R.E. Nichols, and S.H. McNutt. 1952. Studies on corpus luteum ablation and progesterone replacement therapy during pregnancy in the cow. Amer. J. Vet. Res. 13:446-451.

McDonald, L.E., S.H. McNutt, and R.E. Nichols. 1953. On the essentiality of the bovine corpus luteum of pregnancy. Amer. J. Vet. Res. 14:539-541.

Miller W.R., R. Williams, G.W. Pipes, and C.W. Turner. 1963. Conjugation, distribution and biological half-life ( $\mathrm{t} 1 / 2)$ of radioactive progesterone in plasma and red cells of bovine blood. J. Dairy Sci. 46:1402-1404.

Mineo, H., A. Kitade, S. Kawakami, S. Kato, and J. Ushijima. 1990a. Effect of intravenous injection of acetate on the pancreas of sheep. Res. Vet. Sci. 48:310-313.

Monget, P., and G.B. Martin. 1997. Involvement of insulin-like growth factors in the interactions between nutrition and reproduction in female mammals. Reprod. Suppl. $1: 33-51$.

Moor, R.M., and L.E. Rowson. 1960. Egg transfer in sheep. Factors affecting the survival and development of transferred eggs. J. Reprod Fertil. 1:332-349.

Moor, R.M. and Rowson, L. E. A. 1966. Local uterine mechanisms affecting luteal function in the sheep. J. Reprod. Fertil. 11:307.

Morimoto, S., C. Fernandez-Mejia, G. Romerro-Navarro, N. Morales-Peza, and V. DiazSanchez. 2001. Testosterone effect on insulin content, messenger ribonucleic acid levels, promoter activity, and secretion in rats. Endocrinology. 142:1442-1447.

Moutsatsou, P. and C.E. Sekeris. 1997. Estrogen and progesterone receptors in the endometrium. Ann. NY Acad. Sci. 816:99-115.

Muck, W., 2000. Clinical pharmacokinetics of cerivastatin. Clin. Pharmacokinet. 39:99-116.

Nathan, D.M., E. Schreiber, H. Fogel, S. Mojsov, and J.F. Habener. 1992 Insulinotropic action of glucagonlike peptide-I-(7-37) in diabetic and nondiabetic subjects. Diabetes Care 15:270-276.

Niswender, G.D., J.L. Juengel, P.J. Silva, M.K. Rollyson, and E.W. McIntush. 2000. Mechanisms controlling the function and life span of the corpus luteum. Physiol. Rev. 80:1-29.

Nolan, R., D. O’Callaghan, R.T. Duby, P. Lonergan, and M.P. Boland. 1998. The influence of short-term nutrient changes on follicle growth and embryo production following superovulation in beef heifers. Theriogenology 50:1263-1274. 
Northey, D.L. and French, L.R. 1980. Effect of embryo removal and intrauterine infusion of embryonic homogenates on the lifespan of the bovine corpus luteum. J. Anim. Sci. 59:298-302.

NRC. 1985. Pages 2-25 in Nutrient Requirements of Sheep, $6^{\text {th }}$ rev. ed. Natl. Acad. Press, Washington, DC.

O’Callaghan, D., H. Yaakub, P. Hyttel, L.J. Spicer, and M.P. Boland. 2000. Effect of nutrition and superovulation on oocyte morphology, follicular fluid composition and systemic hormone concentrations in ewes. J. Reprod. Fertil. 118:303-313.

Ohashi, M, B.R. Carr, and E.R. Simpson. 1982. Lipoprotein-binding sites in human corpus luteum membrane fractions. Endocrinology. 110:1477-1482.

O’Rahilly, S., R. C. Turner, and D. R. Matthews. 1988. Impaired pulsative secretion of insulin in relatives of patients with non-insulin-dependent diabetes. N. Engl. J. Med. 318:1225-1230.

Palme, R., P. Fischer, H. Schildorfer, and M.N. Ismail. 1996. Excretion of infused ${ }^{14} \mathrm{C}-$ steroid hormones via feces and urine in domestic livestock. Anim. Reprod. Sci.

Papadopoulos, V., H. Amri, H. Li, N. Boujrad, B. Vidic, and M. Garnier. 1997. Targeted disruption of the peripheral-type benzodiazepine receptor gene inhibits steroidogenesis in the R2C Leydig tumor cell line. J. Biol. Chem. 272:32129-32135.

Parkington, H.C. 1983. Electrical properties of the costo-uterine muscle of the guineapig. J Physiol. 335:15-27.

Parr, R.A., I.A. Cumming, and I.J. Clarke. 1982. Effects of maternal nutrition and plasma progesterone concentrations on survival and growth of the sheep embryo in early gestation. J. Agric. Sci. 98:39-46.

Parr, R.A., I.F. Davis, R.J. Fairclough, and M.A. Miles. 1987. Overfeeding during early pregnancy reduces peripheral progesterone concentration and pregnancy rate in sheep. Reprod. Fert. 80:317-320.

Parr, R.A., 1992. Nutrition-progesterone interactions during early pregnancy in sheep. Reprod. Fertil. Dev. 4:297-300.

Parr, R.A., I.F. Davis, M.A. Miles, and T.J. Squires. 1993a. Feed intake affects metabolic clearance rate of progesterone in sheep. Res. Vet. Sci. 55:306-310.

Parr, R.A., I.F. Davis, M.A. Miles, and T.J. Squires. 1993b. Liver blood flow and metabolic clearance rate of progesterone in sheep. Res. Vet. Sci. 55:311-316. 
Pate, J.L. and W.A. Condon. 1982. Effects of serum and lipoproteins on steroidogenesis in cultured bovine luteal cells. Mol. Cell. Endocrinol. 28:551-562.

Pell, J.M., R.A. Hill, C.E. Stewart, C.R. Weston, and H.C. Flick-Smith. 2000. Enhancement of insulin-like growth factor I activity by novel antisera: potential structure/function interactions. Endocrinology. 141:741-751.

Prenant, A. 1898. La valeur morphologique du corps jaune. Son action physiologique et therapeutique possible. (Morphological value of the corpus luteum. Its possible physiological and therapeutic action). Rev. Gen. Sci. Pures. Appl. 9:646-650.

Quinlivan, T.D., C.A. Martin, W.B. Taylor, and I.M. Cairney. 1966. Estimates of pre and perinatal mortality in the New Zealand Romney Marsh ewe. J. Reprod. Fetil. 11:379-390.

Raeside, J.I., and C.W. Turner. 1950. Progesterone in the maintenance of pregnancy in dairy heifers. J. Anim. Sci. 9:681.

Remesy, C. and C. Demigne. 1974. Determination of volatile fatty acids in plasma after ethanolic extraction. Biochem. J. 141:85-91.

Reynolds, C.K., G.B. Huntington, H.F. Tyrrell, and P.J. Reynolds. 1988. Net portaldrained visceral and hepatic metabolism of glucose, L-lactate, and nitrogenous compounds in lactating holstein cows. J. Dairy Sci. 71:1803-1812.

Rhind, S.M., J.J. Robinson, C. Fraser, and I. McHattie. 1980. Ovulation and embryo survival rates and plasma progesterone concentrations of prolific ewes treated with PMSG. J. Reprod. Fertil. 58:139-144.

Rico, A.G. 1983. Metabolism of endogenous and exogenous anabolic agents in cattle. J. Anim. Sci. 57:226-232.

Robinson, T.J. 1951. The control of fertility in sheep. Part II. The augmentation of fertility by gonadotrophin treatment of the ewe in the normal breeding season. J. Agric. Sci. Camb. 41:6-63.

Robinson, N.A., K.E. Leslie, and J.S Walton. 1989. Effect of treatment with progesterone on pregnancy rate and plasma concentrations of progesterone in Holstein cows. J. Dairy Sci. 72:202-207.

Salomon, D., and P. Meda. 1986. Heterogeneity and contact dependent regulation of hormones secretion by individual B-cells. Exp. Cell. Res. 162:507-520.

Samols, E., G. Marri, and V. Marks. 1965. Promotion of insulin secretion by glucagon. Lancet. 2:415. 
Samols, E., J.M. Tyler, and V. Marks. 1972. Glucagon-insulin interrelationships. In Glucagon Molecular Physiology: clinical and therapeutic implication. pp. 151-173. Eds P.J. Lefebvre and R.H. Unger. Oxford:Pergamon.

Sando, H., J. Borg, and D.F. Steiner. 1972. Studies on the secretion of newly synthesized proinsulin and insulin from isolated rat islets of Langerhans. J. Clin. Invest. 51:1476-1485.

Sangsritavong, S., D.K. Combs, R. Santori, L.E. Armentano, and M.C. Wiltbank. 2002. High feed intake increases liver blood flow and metabolism of progesterone and estradiol-17 $\beta$ in dairy cattle. J. Dairy Sci. 85:2831-2842.

Sano, H., S. Tano, H. Takahashi, and Y. Terashima. 1995. Dose response of plasma insulin and glucagon intravenous n-butyrate infusion in sheep. J. Anim. Sci. 73:30383043.

Schmaltz, R. 1921. Das geschlechtsleben der haussaugetiere. (Reproduction of domestic mammals). Richard Schoets Verlag, Berlin, Germany.

Schrick, F.N., and E.K. Inskeep. 1993. Determination of early pregnancy in ewes utilizing transrectal ultrasonography. Theriogenology. 40:295-306.

Schuit, F. C., P. A. In’tveld, and D. G. Pipeleers. 1988. Glucose stimulates proinsulin biosnythesis by a dose-dependent recruitment of pancreatic beta cells. Proc. Natl. Acad. Sci. USA. 85:3865-3869.

Schwalm, J.W., and L.H. Schultz. 1976. Blood and liver metabolites in fed and fasted diabetic goats. J. Dairy Sci. 59:262-269.

Schwarzenberger, F., C.H. Son, R. Pretting, and K. Arbeiter. 1996. Use of group specific antibodies to detect fecal progesterone metabolites during the estrous cycle of cows. Theriogenolgy. 46:23-32.

Sellers, A.F., C.E. Stevens, A. Dobson, and F.D. McLeod. 1964. Arterial blood flow to the ruminant stomach. Am. J. Physiol. 207:371-377.

Selvaraju, S., S.K. Agarwal, S.D. Karche, S.K. Srivastava, A.C. Majumdar, and U. Shanker. 2002. Fertility responses and hormonal profiles in repeat breeding cows treated with insulin. Anim. Reprod. Sci. 2322:1-9.

Shaw, H.J., D.I. Green, A.W. Sainsbury, and W.V. Holt. 1995. Monitoring ovarian function in scimitar-horned oryx (Oryx dammah) by measurement of fecal $20 \alpha-$ progestagen metabolites. Zoo. Biol. 14:239-250. 
Sheffel, C.E., B.R. Pratt, W.L. Ferrell and E.K. Inskeep. 1982. Induced corpora lutea in the postpartum beef cow. II. Effects of treatment with progestogen and gonadotropins. J. Anim. Sci. 54:830-836.

Shevah, Y., W.J.M. Black, W.R. Carr, and R.B. Land. 1975. The effects of nutrition on the reproductive performance of Finn x Dorset ewes. J. Reprod. Fert. 45:283-288.

Shideler, S.E., A.M. Ortuno, F.M. Moran, E.A. Moorman, and B.L. Lasley. 1993. Simple extraction and enzyme immunoassays for estrogen and progesterone metabolites in the feces of Macaca fascicularis during non-conceptive and conceptive ovarian cycles. Biol. Reprod. 48:1290-1298.

Sidhu, J.S. and C.J. Omiecinski. 1999. Insulin-mediated modulation of cytochrome P450 gene induction profiles in primary rat hepatocyte cultures. J. Biochem. Toxicol. 13:1-9.

Sidhu, J.S., F. Liu, S.M. Boyle, and C.J. Omiecinski. 2001. PI3K inhibitors reverse the suppressive actions of insulin on CYP2E1 expression by activating stress-response pathways in primary rat hepatocytes. Mol. Pharmacol. 59:1138-1146.

Simpson, RB, C.C. Chase Jr, L.J. Spicer, R.K. Vernon, A.C. Hammond, and D.O. Rae. 1994. Effect of exogenous insulin on plasma and follicular insulin-like growth factor I, insulin-like growth factor binding protein activity, follicular oestradiol and progesterone, and follicular growth in superovulated Angus and Brahman cows. J. Reprod. Fertil. 102:483-492.

Sinclair, K.D., M. Kuran, F.E. Gebbie, R. Webb, and T.G. McEvoy. 2000. Nitrogen metabolism and fertility in cattle. II. Development of oocytes recovered from heifers offered diets differing in their rate of nitrogen release in the rumen. J. Anim. Sci. 78:2670-2689.

Skarda, J., and S. Bartos. 1969. The effect of insulin on the utilization of $\left[\mathrm{U}-{ }^{14} \mathrm{C}\right]$ glucose and $\left[\mathrm{I}-{ }^{14} \mathrm{C}\right]$ acetateby goat adipose tissue in vitro. J. of Endo. 44:115-119.

Sonnichsen, D.S., Q. Liu, E.G. Schuetz, J.D. Shuetz, A. Pappo, and M.V. Relling. 1995. Variability in human cytochrome-P450 paclitaxel metabolism. J. Pharmacol. Exp. Ther. 275:566-575.

Sorensen, R. L., M.W. Steffes, and A. W. Lindall. 1970. Subcellular localization of proinsulin to insulin conversion in isolated rat islets. Endocrinology. 86:88.

Spitzer, J.C., G.D. Niswender, G.E. Seidel Jr., and J.N. Wiltbank. 1978. Fertilization and blood levels of progesterone and LH in beef heifers on a restricted energy diet. J. Amin. Sci. 46:1071-1077. 
Sreenan, J.M., M.G. Diskin, and M. Murphy. 1979. Fertilization and embryo survival rates in control and progesterone or hCG treated heifers. Ann. Biol. Anim. Biochim. Biophys. 19:1619.

Sreenan, J.M., and M.G. Diskin. 1983. Early embryonic mortality in the cow: it's relationship with progesterone concentration. Vet. Rec. 112:517-521.

Stangner, J., E. Samols, and G. Weir. 1980. Sustained oscillations of insulin, glucagon, and somatostatin from the isolated canine pancreas during exposure to a constant glucose concentration. J. Clin. Invest. 65:939-942.

Staigmiller, R.B., R.B. Short, R.A. Bellows and J.B. Carr. 1979. Effect of nutrition on response to exogenous FSH in beef cattle. J. Anim. Sci. 48:1182-1190.

Starbuck, M.J. 2001. Retention of early pregnancy and its relationship to serum progesterone in dairy cattle. M.S. Thesis. West Virginia University, Morgantown.

Stefan, Y., P. Meda, M. Neufeld, and L. Orci. 1987. Stimulation of insulin secretion reveals heterogeneity of pancreatic B-cells in vivo. J. Clin. Invest. 80:175-183.

Steiner, D. F., D. D. Cunningham, L. Spigelman, and B. Aten. 1967. Insulin biosynthesis: evidence for a precursor. Science (Washington). 157:697.

Steiner, D. F. 1967. Evidence for a precursor in the biosynthesis of insulin. Trans. N. Y. Acad. Sci. 30 (No. 1):60.

Steiner, D F., J. L. Clark, C. Nolan, A. H. Rubenstein, E. Margoliash, F. Melani, and P. E. Oyer. 1970. The biosynthesis of insulin and some speculations regarding the pathogenesis of human diabetes. In The Pathogenesis of Diabetes Mellitus. Proceedings of the Thirteenth Nobel Symposium. E. Cerasi and R. Luft, editors. Almqvist \& Wiksell, Publishers, Stockholm. 123.

Steinhour, W.D., and D.E. Bauman. 1988. Propionate metabolism: a new interpretation. In Aspects of Digestive Physiology in Ruminants. Eds. A. Dobson and M.J. Dobson. Ithaca, NY. pp. 238-256.

Stern, J. S., C. A. Baile, and J. Mayer. 1970. Are propionate and butyrate physiological regulators of plasma insulin in ruminants? Am. J. Physiol. 210:365.

Stevenson, J.S., and M.O. Mee. 1991. Pregnancy rates of Holstein cows after postinsemination treatment with a progesterone-releasing intravaginal device. J. Dairy Sci. 74:3849-3856.

Stewart, R.E., L.J. Spicer, T.D. Hamilton, B.E. Keefer, L.J. Dawson, G.L. Morgan, and S.E. Echternkamp. 1996. Levels of insulin-like growth factor (IGF) binding proteins, luteinizing hormone and IGF-I receptors, and steroids in dominant follicles during the 
first follicular wave in cattle exhibiting regular estrous cycles. Endocrinology. 137:2842-2850.

Stone, D., and O. Hechter. 1954. Studies on ACTH action in perfused bovine adrenals: aspects of progesterone as an intermediary in corticosteroidogenesis. Arch Biochem. 54:121-128.

Stupnicki, R., J.A. McCracken, and K.I.H. Williams. 1969. Progesterone metabolism in the ewe. J Endocrinol. 45:67-74.

Tanabe, T.Y. 1966. Essentiality of the corpus luteum for maintenance of pregnancy in dairy cows. J. Dairy Sci. 49:731.

Tanabe, T.Y. 1970. The role of progesterone during pregnancy in dairy cows. Pennsylvania Agricultural Experiment Station Bulletin, University Park. 774:1-61.

Tang, C., M. Shou, Q. Mei, T.H. Rushmore, and A.D. Rodrigues. 2000. Major role of human liver microsomal cytochrome P450 2C9 (CYP2C9) in the oxidative metabolism of celecoxib, a novel cyclooxygenase-II inhibitor. J. Pharmocol. Exp. Ther. 293:453-459.

Taylor, W. 1971. The excretion of steroid hormone metabolites in bile and feces. Vitam. Horm. 29:201-285.

Tezuka, N.M., M. Ali, K. Chwalisz, and R.E. Garfield. 1995. Changes in transcripts encoding calcium channel subunits of rat myometrium during pregnancy. Am J Physiol. 269:1008-1017.

Trenkle, A. 1970. Effects of short-chain fatty acids, feeding, fasting, and type of diet on plasma insulin levels in sheep. J. Nutr. 100:1323-1330.

Tsai SJ, M.C. Wiltbank, and K.J. Bodensteiner. 1996. Distinct mechanisms regulate induction of messenger ribonucleic acid for prostaglandin (PG) G/H synthase-2, PGE (EP3) receptor, and PGF2alpha receptor in bovine preovulatory follicles. Endocrinology. 137:3348-3355.

Turner, D. S., and N. McIntyre. 1966. Stimulation by glucagon of insulin release from rabbit pancreas in vitro. Lancet. 1:351.

Valverde, A.M., M. Lorenzo, T. Teruel, and M. Benito. 1997. Alterations in the Insulin Signaling Pathway Induced by Immortalization and H-ras Transformation of Brown Adipocytes. Endocrinology. 138:3195-3207.

Verhage, H.G. and A.T. Fazleabas. 1988. The in vitro synthesis of estrogen-dependent proteins by the baboon (Papio anubis) oviduct. Endocrinology. 123:552-558. 
Wang, J. L., and M. L. McDaniel. 1990. Secretagogue-induced oscillations of cytoplasmic $\mathrm{Ca} 2+$ in single $\beta$ and $\alpha$ cells obtained from pancreatic islets by fluorescenceactivated cell sorting. Biochem. Biophy. Res. Commun. 166:813-818.

Waterman, M.R. 1995. A rising StAR: an essential role in cholesterol transport. Science. 267:1780-1781.

Webster, A.J., P.O. Osuji, F. White, and J.F. Ingram. 1975. The influence of food intake on portal blood flow and heat production in the digestive tract of sheep. Br. J. Nutr. 34:125-139.

Weir, G.C. and S.B. Weir. 1990. Islets of Langerhans: The puzzle of intraislet interactions and their relevance to diabetes. J. Clin. Invest. 85:983-987.

West NB, M.C. McClellan, M.D. Sternfeld, and R.M. Brenner. 1987.

Immunocytochemistry versus binding assays of the estrogen receptor in the reproductive tract of spayed and hormone-treated macaques. Endocrinology. 121:1789-1800.

Westwood, C.T., I.J. Lean, and R.C. Kellaway. 1998. Indications and implications for testing of milk urea in dairy cattle: a quantitative review Part 2. Effect of dietary protein on reproductive performance. N.Z. Vet. J. 46:123-140.

Wieghart, M., R. Slepetis, J.M. Elliot, and D.F. Smith. 1986. Glucose absorption and hepatic gluconeogenesis in dairy cows fed diets varying in forage content. J. Nutr. 116:839-850.

Williams, W.F. 1962. Excretion of progesterone and its metabolites in milk, urine, and feces. J. Dairy Sci. 45:1541-1542.

Wiltbank, J.N., H.W. Hawk, H.E. Kidder, W.G. Black, L.C. Ulberg, and L.E. Casida. 1956. Effect of progesterone therapy on embryo survival in cows of lowered fertility. J. Dairy Sci. 39:456-461.

Woodcroft, K.J., and R.F. Novak. 1999. The role of phosphatidylinositol 3-kinase, Src kinase, and protein kinase A signaling pathways in insulin and glucagon regulation of CYP2E1 expression. Biochem. Biophys. Res. Commun. 266:304-307.

Yamazaki, H., K. Inoue, P.M. Shaw, W.J. Checovich, F.P. Guengerich, and T. Shimada. 1997. Different contributions of cytochrome P450 2C19 and 3A4 in the oxidation of omeprazole by human liver microsomes; effects of contents of these two forms in individual human samples. J. Pharmacol. Exp. Ther. 238:434-442.

Yang, Y.T., and R.L. Baldwin. 1973. Preparation and metabolism of isolated cells from bovine adipose tissue. J. Dairy Sci. 56:350-365. 


\section{VITA}

Name: Darron Louis Smith

Parents: Gale W. and Emily G. Smith

Birth place: Bryn Athyn, Pennsylvania

Date of Birth: July 17, 1963

\section{Schools Attended:}

Academy of the New Church - 1968 to 1982, Bryn Athyn, Pennsylvania

The Pennsylvania State University - 1995 to 1999, State College, Pennsylvania

Colorado State University - 1999, Fort Collins, Colorado

West Virginia University - 2002 to 2005, Morgantown, West Virginia

\section{Degrees Received:}

Bachelor of Animal Science - The Pennsylvania State University 